\title{
The Graying of Civil Rights Law: The Age Discrimination Act of 1975
}

\author{
Peter H. Schuck*
}

Nondiscrimination laws have come to play a central role in the design of public policy in the modern welfare state. Such laws place those who administer them in the difficult business of allocating scarce resources, regulating conflicting interests, and attempting to shape complex institutional behavior. The egalitarian vision that inspires such laws and the rhetorical and political energy that generate their enactment, however, are not easily accommodated to the underlying moral and decisional complexities of the regulatory task. These complexities inevitably disturb the tranquil surface of the law where formal simplicity and moral clarity dwell.

This Article examines the Age Discrimination Act of $1975^{1}$ (ADA), and explores the conflict between the criteria of social choice that decisionmakers wish to employ, and the moral and legal constraints that nondiscrimination laws seek to impose upon such criteria. The Article consists of four parts. Part I describes the ADA and contrasts it with earlier nondiscrimination laws, especially the prohibition on race discrimination in Title VI of the Civil Rights Act of 1964. A critical analysis of the putative analogy between race discrimination and age discrimination reveals the distinctive characteristics of age and the principal considerations that ought to govern the use of age as a criterion of classification. I argue that the ADA's attempt to fuse two distinct types of group protection statutes has yielded a hybrid form that constitutes a problematic policy instrument.

Part II traces the evolution of the ADA: the legal and political contexts out of which it emerged; its legislative history; the Civil Rights Commission study on age discrimination mandated by the ADA; and

- Associate Professor of Law, Yale Law School. While serving as Deputy Assistant Secretary for Planning and Evaluation, Department of Health, Education, and Welfare, the author participated in HEW's efforts to implement the Age Discrimination Act of 1975. He wrote the initial draft of this Article while a Visiting Scholar at the American Enterprise Institute for Public Policy Research, and wishes to acknowledge the helpful comments of Bruce Ackerman, Owen Fiss, Julius Getman, Paul Gewirtz, Daniel Givelber, Danicl Meltzer, and several HEW colleagues on earlier versions.

1. 42 U.S.C. $\$ \$ 6101-6107$ (1976) as amended by Amendments to the Older Americans Act of 1965, Pub. L. No. 95-478, 92 Stat. 1555 (1978). 
the 1978 amendments to the statute. This account (as I argue in Part IV) reveals a sweeping abdication by Congress and the Executive Branch of their most elementary policymaking functions, leaving a conceptual void concerning the nature of the age discrimination problem. Part III analyzes the principal legal and policy issues that agencies and courts must resolve as they interpret the broad statutory exclusions and exceptions in the ADA. Employing the approach to age discrimination presented in Part I, I argue that the ADA's exceptions should be construed in a latitudinarian fashion, leaving most age classifications intact.

Part IV develops some of the themes adumbrated earlier in the Article. In particular, I argue that the breakdown of the conventional policymaking process both affected and was affected by a confusion about the nature and extent of age discrimination, and that this breakdown led directly to the distinctive kind of hybrid legislative form that constitutes the ADA. I conclude by considering some possible consequences of the $\mathrm{ADA}$ for the substance and process of social welfare policy.

\section{Defining the Problem: The ADA and the Analogy to Title VI}

\section{A. The Statutory Scheme}

The essential structure of the ADA is simple. It prohibits discrimination on the basis of age in all federally assisted programs and activities, ${ }^{2}$ and then excludes from coverage those programs or activities "established under authority of any law" employing age criteria to condition benefits or participation, ${ }^{3}$ as well as certain employmentrelated programs or activities. ${ }^{4}$ In addition, the statute provides several broadly worded "reasonableness" exceptions from the prohibition." Finally, it requires each federal agency or department to issue implementing regulations; ${ }^{6}$ enforcement of the statute is to be by the agencies and departments ${ }^{7}$ and, after the 1978 amendments, by private court action. ${ }^{8}$

2. 42 U.S.C. $\$ 6101$ (1976).

3. $I d . \S 6103(\mathrm{~b})(2)$.

4. $I d . \S 6103(c)(1)$ (broadly excluding practices of any employer, employment agency, labor organization, or labor-management joint-apprenticeship program receiving Comprehensive Employment and Training Act funds).

5. $I d . \S 6103(\mathrm{~b})(1)(\mathrm{A})-(\mathrm{B})$.

6. Id. $\S 6103(\mathrm{a})$.

7. Id. $\$ 6104$.

8. Amendments to the Older Americans Act of 1965, Pub. L. No. 95-478, $\$ 401$ (c), 92 Stat. 1555 (1978) (codified at 42 U.S.C.A. $\$ 6104$ (West 1979)). 
The ADA is the offspring of-indeed, is expressly modeled uponTitle VI of the Civil Rights Act of $1964,{ }^{9}$ which prohibits discrimination on the basis of race, color, or national origin in federally assisted programs. The ADA employs prohibitory language virtually identical to that in Title VI and in its progeny, Title IX of the Education Act of $1972^{10}$ and section 504 of the Rehabilitation Act of 1973.11 In its various statutory contexts, this language confers upon a large number of individuals a legal remedy against discrimination on the basis of particular characteristics-race, color, national origin, and handicap-in the vast range of activities that receive some federal assistance. ${ }^{12}$ In adding age to the list of protected characteristics, Congress stressed that the ADA does not protect merely the elderly or persons who attain a particular age, but all persons at all times during their lives. ${ }^{13}$ Nevertheless, Congress clearly had the elderly primarily in mind..$^{14}$

9. 42 U.S.C. $\$ 2000 \mathrm{~d}$ (1976) [statute hereinafter cited as Title VI]; see H.R. REP. No. 670, 94th Cong., 1st Sess. 56 (1975) reprinted in part in [1975] U.S. CodE CoNG. \& AD. News 1290, 1323 (noting Title VI was model for ADA but stressing significant differences) [hereinafter cited as CONFERFNCE REPORT with citations to pages in original Report].

10. 20 U.S.C. $\$ \$ 1681-1686$ (1976) (prohibiting sex discrimination in federally assisted educational programs) [statute hereinafter cited as Title IX].

11. 29 U.S.C. $\$ 794$ (1976) (prohibiting discrimination on basis of physical or mental handicap in federally assisted programs).

12. Other modern civil rights provisions are more restricted in scope because of limits on either the size of the protected group or the range of activities affected. Other than the ADA, the central statute protecting the elderly is the Age Discrimination in Employment Act of 1967, 29 U.S.C. $\$ \S 621-634$ (1976), as amended by Pub. L. No. 95-256, $\S 2$ (a), 92 Stat. 189 (1978) [hereinafter cited as ADEA], which prohibits discrimination in employment against persons aged 40 to 65 (or to age 70 for certain categories of employment). For examples of other limited civil rights provisions, see Title VII of the Civil Rights Act of 1964, 42 U.S.C. $\$ 2000$ e (1976) (prohibiting discrimination in employment on basis of race, color, religion, sex, or national origin) and the Education for All Handicapped Children Act of 1975, 20 U.S.C. $\$ \S 1401-1412(1)$ (1976) (establishing requirements for educating handicapped children).

13. See, e.g., H.R. REP. No. 67, 94th Cong., 1st Sess. 16 (1975) (Older Americans Amendments of 1975 "aimed at eliminating age discrimination at all levels") [hereinafter cited as House RePORT]; I2I CoNG. REC. 9212 (1975) (remarks of Rep. Brademas).

14. 121 Conc. Rec. 9212 (1975) (remarks of Rep. Brademas) (noting act is principally intended to counteract prejudice against elderly). Thus, the ADA implicitly pursues somewhat conflicting goals: prohibition of differential treatment on the basis of age ("age-blindness"), and preference for a particular age group thought to be especially disadrantaged. This conflict between the desire to render the law "blind" as to a particular attribute and the desire to prefer one group thought to be disadvantaged because of that attribute in its competition with others is not confined to the ADA. The Supreme Court has held that Title VI and Title VII were not intended to be "colorblind," but rather envisioned preferential treatment on behalf of blacks. United Steelworkers of America v. Weber, 99 S. Ct. 2721, 2727-28 (1979) (Title VII did not intend wholly to prohibit private, voluntary affirmative action); Regents of the Univ. of Cal. v. Bakke, 438 U.S. 265, 284-87 (1978) (Powell, J., announcing judgment of the Court) (Title VI proscribes only those racial classifications that would violate equal protection clause). Title IX, while in terms "sex-blind," was enacted with women in mind as the group 
Although enacted in 1975 , the ADA is only now, four years later, about to be fully implemented. ${ }^{15}$ It will apply predominantly, but not exclusively, to the rapidly growing public sector. ${ }^{16}$ As discussed later, the ADA, like Title VI and section 504 before it, may well require far-reaching changes in the ways in which public and private agencies conduct their activities: the age distribution of the populations they serve; how they identify and communicate with clients; how and where they render services; how and to what extent they collect information; and many other aspects of their operations.

However it may be interpreted and implemented, the ADA, like all broad-ranging civil rights statutes, will generate much uncertainty and litigation. Some uncertainty is inevitable and indeed appropriate-the purpose of reform, after all, is to unsettle existing human and institutional relationships and to generate new ones. Much of it, however, derives from a conceptual ambivalence manifested in the statute itself. The ADA was premised upon a fundamental analogy between race discrimination and age discrimination, an analogy whose influence pervades the legislative history of the $\mathrm{ADA}$ and finds expression in the use of a nondiscrimination provision drawn verbatim from Title VI. ${ }^{17}$ Yet that prohibition was made subject to exceptions and exclusions so broad that they arguably deprive the prohibition of any significant effect. ${ }^{18}$ As discussed later, this ambivalence, so central

most requiring protection. The extent to which the ADA was intended to be "age-blind," however, remains uncertain. It seems unlikely that Congress intended to call into question the validity of numerous statutes that prefer the interests of one age group over those of others. See pp. 62-63 infra. On the other hand, Congress did intend to protect the interests of all age groups, especially in the absence of any history of oppression of one age group by another; here, as elsewhere, the analogy to race breaks down.

15. Implementation began pursuant to HEW's issuance of general governmentwide regulations on June 12, 1979, 44 Fed. Reg. 33,768-80 (1979) (to be codified at 45 C.F.R. $\$ 90$ ), as required by the ADA, 42 U.S.C.A. $\$ 6103(\mathrm{a})(\mathrm{I})$ (West 1979). Regulations consistent with those governmentwide regulations must next be issued by "each Federal department or agency which extends Federal financial assistance to any program activity by way of grant, entitlement, loan or contract other than a contract of insurance or guaranty." Id. $\$ 6103(\mathrm{a})(4)$.

16. HEW estimates that the ADA will apply to nearly 100,000 public and private entities that receive federal financial assistance, and to as many as 450,000 sub-recipients (that is, those who secure aid from the direct recipients). These entities range from hospitals, schools, and mass transit systems to legal services offices, libraries, and housing projects. The ADA also applies to private organizations, such as the Junior Chamber of Commerce or senior citizens' clubs, if they directly or indirectly receive federal financial assistance. See Memorandum from Office of Program Systems, HEW (Jan. 15, 1979) (estimates of primary recipients) (memorandum on file with Yale Law Journal). The estimate of sub-recipients was compiled by the Office of Civil Rights, HEW (1978).

17. See note 9 supra.

18. See, e.g., 42 U.S.C. $\$ 6103(b)(1)(1976)$ (authorizing cxception for any action that "reasonably takes into account age as a factor necessary to the normal operation ... of [a] program or activity" or that makes a "differentiation ... based upon reasonable 
to the impact of the ADA, was not even discussed, much less explained, in its scant legislative history. ${ }^{19}$ Similarly, the phenomenon of age discrimination in federally assisted activities was neither documented nor even well-defined prior to enactment of the $A D A . .^{20}$ In short, the ADA was premised upon an analogy that was explicitly affirmed, implicitly denied, and nowhere analyzed.

\section{B. The Substance of Policy: The Analogy Explored}

The ADA's core provisions raise three critical policy issues that were not considered by its authors: (l) The ways in which decisionmakers use age to distinguish between people and the reasonableness of those uses in light of their consequences and the social values they implicate; (2) The reasonableness of the use of facially neutral factors other than age with different age groups are thereby affected differently; and (3) The burden of justification to which society is prepared to hold age distinctions and uses of non-age factors. An analysis of these issues suggests an appropriate conceptualization of the age discrimination problem.

The Reasonableness of Using Age to Classify Persons. Existing law is anything but "age-blind"; it employs age distinctions in numerous contexts. Age is used as a proxy for, or as a predictor of, many characteristics thought to be correlated with age. ${ }^{21}$ Thus, age is commonly

factors other than age"). It is instructive to compare the ADA with the ADEA, see note 12 supra, which contains several exceptions, two of which are closely related to two of the ADA exceptions. 29 U.S.C. $\$ 623(f)$ (1976) (providing exceptions for "bona fide occupational qualification" and "reasonable factors other than age"); see pp. 66-71 infra (comparing exceptions). In addition, the ADEA authorized the creation of exceptions by regulation. See 29 U.S.C. $\$ 628$ (1976). Title VII of the Civil Rights Act of 1964, see note 12 supra, also contains a "reasonably necessary to the normal operation" exception. 42 U.S.C. $\$ 2000 \mathrm{c}-2$ (c) (1976); see pp. 66-71 infra (discussing relevance to ADA exceptions). Title IX contains numerous exceptions, but each is quite narrow and specific. See 20 U.S.C. $\$ 1681$ (a) (1976). Indeed, many of the exceptions are absurdly specific. See, e.g., id. $\$ 1681(\mathrm{a})(8)$ (exception for father-son or mother-daughter activities); id. $\$ 1681$ (a)(9) (exception for scholarship awards in beauty pageants).

19. See pp. 46-49, 55-58 infra (legislative history of ADA and amendments). The thin legislative record of the ADA contrasts sharply with the extensive record of Title VI. See Regents of the Univ, of Cal. v. Bakke, 438 U.S. 265, 284 (1978) (Powell, J., announcing judgment of the Court) (describing Title VI's legislative history as "voluminous").

20. Cf. U.S. Dep't of Labor, Report to the Congress on Age Discrimination in EMployment UNDER SEction 715 of THE Civil Rights Act of 1964, at 18-19 (1965) (age discrimination in employment described as pervasive).

The contrast with race discrimination, the incidence of which has been well documented, is again striking. See, e.g., G. MYrdal, AN AMERICAN Dilemma (1944) (examining white-black relations in American society); U.S. NAtional Advisory Comm'N ON Civil DisoRDERs, REPORT 95-113 (1968) (describing history of racism in America).

21. The characteristic for which age is intended to be a proxy is not always clear. In extending transit-fare discounts to the elderly, for example, age may be considered a 
used as a measure of intellectual, physical, or emotional maturity (as in minimum-age requirements for certain educational programs); of readiness to assume adult responsibilities (as in minimum-age requirements for voting, consuming alcohol, or possessing firearms); of the likelihood of possessing certain risk factors (as in concentrating breast cancer screening programs on women above a certain age); of certain physical abilities (as in separating sports leagues by age); of the expected duration of future employability or service (as in concentrating job-training programs on younger workers or limiting enrollment in medical schools to persons under a certain age); or of the likelihood of experiencing particular kinds of problems (as in medical programs that specialize in serving certain age groups).

These classifications typically treat one age group differently than another and frequently exclude one age group from a benefit altogether. ${ }^{22}$ Because different groups may include individuals who are alike in all relevant characteristics save age, applying such rules can appear harsh and unjust to those individuals disadvantaged by them. On the other hand, countervailing reasons-such as equitable or administrative considerations-often militate in favor of such rules. Ultimately, the reasonableness of any particular age classification must rest upon the consequences of using such proxies or predictors in the contexts in which they actually operate. ${ }^{23}$

A rule containing an age criterion may be opposed on grounds both of principle and of expediency. First, such a rule classifies individuals

proxy for low-income status and dependency upon mass transit. Age is clearly a very crude proxy, however, for such characteristics. In fact, only one-seventh of the elderly have incomes below the poverty threshold. Bureau of Census, U.S. DeP'T of Commerce, StatisTICAL ABSTRACT OF THE UNITED STATES 472 (1978) (listing characteristics of persons 65 and over) [hereinafter cited as Statistical ABstract]. This particular age classification may actually reflect the political influence of the elderly relative to other low-income or transitdependent groups and the relative administrative simplicity of using age as the qualifying characteristic.

22. An age criterion is perhaps the classic example of the "formally realizable rule"a criterion of decision whose applicability is readily ascertainable by the investigation of relatively unambiguous, objective facts. The virtue of such a rule is certainty of application; because little or no discretion is required to apply it to particular fact situations, it is unlikely to be applied erroneously. See Kennedy, Form and Substance in Private Law Adjudication, 89 HARv. L. REv. 1685, 1687-1701 (1976) (exploring characteristics and moral and jurisprudential underpinnings of formally realizable rules).

23. Cf. Underwood, Law and the Crystal Ball: Predicting Behavior with Statistical Inference and Individualized Judgment, 88 Y ALE L.J. 1408, 1420.32 (1979) (contrasting clinical and statistical decisionmaking). Professor Underwood examines the consequences of employing different kinds of predictive processes and criteria. Age is often used as a predictive criterion, as with the minimum drinking age, but is also used when prediction of future behavior is not the purpose of the classification, as with the provision of Social Security retirement benefits at designated ages. Age rules are employed not only as auguries of future behavior but also as proxies for present capacities or attributes. 
on the basis of a characteristic that is immanent and inescapable to them, one suggestive of neither culpability nor demerit. To disadvantage an individual solely because he or she possesses such a characteristic offends deeply held notions of fairness; the attribute is, by hypothesis, one over which the individual has no control and for which he or she therefore cannot be held morally responsible. ${ }^{24}$ Second, the use of age criteria will often reflect and reinforce stereotypes about particular age groups that adversely affect the self-image of members of that group and encourage others in society to behave as if such generalizations were in fact accurate. The vice of such stereotypes extends beyond the fact that they can become self-fulfilling prophecies; ${ }^{25}$ by imputing attributes to people solely on the basis of group membership, they derogate from the uniqueness of individuals, often producing factually inaccurate predictions in particular cases. Finally, age criteria may be considered objectionable because they redound to the disadvantage of groups, such as the elderly or children, whom society believes deserving of special protection or concern, often in the form of increased public benefits and services.

To each of these arguments against the use of age classifications, a strong counterargument may be made in its favor. If being a particular age, like being a particular race, is an immanent, inescapable attribute, it is also one that each of us presumably has experienced or will experience; ${ }^{26}$ members of other age groups are surely less likely to use age rules to oppress persons whose status they have shared or expect to share. Moreover, the fact that one cannot alter one's age is not necessarily an argument against an age classification. It is one thing to say that a classification stigmatizes or condemns, and quite another to say that it places one at a disadvantage vis-a-vis others. Few, if any, age classifications fall into the former category; rather, they simply use age as a basis for allocating benefits between competing claimants. Under these circumstances, it may well be that using an immanent, impersonal characteristic such as age to determine one's

24. See Underwood, supra note 23, at 1436 (factors beyond individual's control threaten autonomy and prevent individuals from improving their chances).

25. An example may illustrate the self-fulfilling nature of such stereotypes. Use of an age ceiling in job programs will reduce job opportunities for the elderly, thereby reinforcing the view-in the minds of the elderly as well as of employers-that the elderly are not employable or interested in working. For just such reasons, the Supreme Court has denounced some sex classifications as reflective of " "old notions." "Stanton v. Stanton, 421 U.S. 7, 14 (1975) (quoting decision below, 30 Utah 2d 315, 318, 517 P.2d 1010, 1012 (1974)).

26. See Underwood, supra note 23 , at 1436 ("it may be important [in using age as a criterion] that an individual is not bound to one age forever"). 
entitlement to benefits is less stigmatizing or damaging than doing so on the basis of a characteristic, such as maturity or employability, that reflects directly upon one's personal merit. ${ }^{2 \pi}$

Objection to age classifications on the ground that they reflect or even reinforce stereotypes proves far too much, for it applies equally to any broad classification of individuals. The rationality of any classification depends primarily upon the extent to which the persons so classified in fact possess the characteristic upon which the classification is based. Almost inevitably, classifications embracing large populations will be "under-inclusive" or "over-inclusive." At some cost, it will always be possible to obtain a better fit between the classificatory means and the programmatic end by using the characteristic itself, rather than the age-proxy, as the criterion for classification. In this respect, age classifications do not differ, except perhaps in degree, from those based upon other characteristics. ${ }^{28}$ The appropriate question in every case, however, is not whether a classification is based upon a stereotype or whether the classification effects a perfect fit; rather, the question should be whether the disadvantages of an imperfect fit are more than compensated for by the practical advantages of employing the particular classification.

In the case of age classifications, these practical advantages are often considerable. Age is a highly objective, easily measured characteristic, especially when compared to those qualities, such as maturity or susceptibility to certain physical conditions, for which it often serves as a proxy. Thus, age classifications can be administered more easily than those dependent upon criteria that are difficult to measure directly or that require individualized determinations. ${ }^{29}$ Furthermore, the relative objectivity and ease of administration of age rules suggest that their applicability, as distinguished from their reasonableness, will seldom

27. Cf. M. Young, The Rise of the Meritocrac' 1870-2033 (1958) (suggesting that in genuine meritocracy, those who fared poorly would feel greater despair because closer correlation between status and personal deficiencies would aggravate stigma).

28. It is difficult, perhaps impossible, to say whether age classifications produce better or worse fits than any of the other single-criterion classifications, such as education level, place of residence, or marital status, that are employed in social legislation. All classifications will be imperfect to some degree.

29. See Cleveland Bd. of Educ. v. LaFleur, 414 U.S. 632, 657.59 (1974) (Rehnquist, J., dissenting) (noting social value of criteria that avoid need for individual determinations). To the reduced administrative costs, of course, must be added the costs of the marginal under- or over-inclusiveness of the age rule when compared with the better fitting, but difficult to administer, classification that might be used instead of agc. See Orr v. Orr, 99 S. Ct. 1102, 1112-13 (1979) ("even if sex were a reliable proxy for need" for financial assistance, sex distinction would be invalid where individualized determinations would cause no additional burden); Craig v. Boren, 429 U.S. 190, 198.204 (1976) (discussing relationship between administrative convenience and use of sex-proxies). 
be controversial. ${ }^{30}$ This constrained discretion constitutes an essential safeguard not only against bias or arbitrariness in the application of such rules but also against good faith bureaucratic error.

Another advantage in using age as a classificatory criterion is that the immanence of age prevents individuals from manipulating it (as they might, for example, their income). Thus, individuals are unlikely to modify their behavior in response to the incentives created by the age rule, and the consequences of using such rules will be relatively predictable.

The final objection to the use of age rules-that they unfairly burden certain groups-amounts to an assertion that those groups should receive a different (and presumably greater) share of public resources than they would enjoy in the absence of such rules. Such an assertion can be neither refuted nor affirmed by recourse to any logical principle or empirical datum. It is only fair to observe, however, that the assertion that a particular group should receive more is rarely accompanied by an assertion that other groups should receive less, yet if resources remain unchanged, the latter is the inevitable implication of the former. ${ }^{31}$

For all of these reasons, a principle that age may never be employed as a classificatory criterion seems impossible to justify. On the other hand, it may well appear that a particular age classification is arbitrary and thus not supportable under the ADA's "reasonableness" exceptions. As the preceding discussion suggests, however, such a judgment would reflect more than an evaluation of the likely consequences of using age as a criterion in that particular context; it would require in addition a choice between ineluctably conflicting social values. ${ }^{32}$

The Reasonableness of Using Non-Age Factors That Create AgeSpecific Differential Impacts. Typically, the criterion used to distinguish between people in the distribution of public benefits is not age itself but some other facially neutral factor such as income. Where the effect of using such a non-age factor is to advantage some age groups over others, it could be argued-again, on an analogy to race discrimination-that use of that factor constitutes prima facie age discrimination. Such an argument, if accepted, would have far-reaching implications. Such factors are numerous, reflecting the myriad considerations used by legislators, program officials, and administrators

30. See Kennedy, supra note 22, at $1687-89$ (such rules have virtues of certainty and of restraining arbitrariness).

31. See p. 75 infra (discussion of "zero-sum game" aspect of $\mathrm{ADA}$ ).

32. Cf. Underwood, supra note 23, at $1447-48$ ("choice of factors, then, for use in a predictive scheme implicates values that sometimes point in different directions"). 
to target resources, define needs, restrict eligibility, and shape service delivery patterns in particular social and political contexts. Most important, these factors almost certainly will generate different impacts for different age groups. Each point in the life cycle tends to be associated with different distributions of non-age factors. ${ }^{33}$ Furthermore, the actual distribution of needs among age groups in any particular case may well be impossible to determine. ${ }^{34}$ Thus, the uncertain significance of "disproportionate impact" with respect to

33. Consider, for example, two fundamental program decisions: the benefit or service to be provided, and the allocation of scarce resources among eligible persons. Many needs that programs and activities attempt to address are more characteristic of some age groups than of others: the need for the basic skills and socialization that public schools provide is found far more commonly among children than among elderly people; the need for the long-term health care that nursing homes provide is found far more frequently among the elderly. Provision of any of these services will affect different age groups differently.

It is difficult to conceive of a criterion for rationing limited program benefits among a large pool of eligible persons-an imperative in most programs and activities subject to the ADA-that would not have differential age-specific impacts. A means test or fee schedule, for example, will disadvantage age groups that are on average less affluent (e.g., children, unemployed teenagers, the retired elderly). Age groups are not geographically distributed in uniform fashion; thus, any facility-location criterion (e.g., convenience to public transit) will tend to favor those age groups that live disproportionately in proximate neighborhoods. Use of test scores may well disadvantage the elderly relative to those more accustomed to test-taking. A first-come, first-served criterion will tend to favor age groups that are more mobile and better informed about available benefits. Use of waiting lines will tend to favor those age groups with more leisure time (e.g., the elderly) over those who are fully employed (e.g., the middle-aged).

34. We cannot readily determine in an objective (as opposed to political) fashion which age groups need which services or benefits in what amounts. Reliable data rarely exist as to the relative desire of various age groups for the numerous age-specific programs or benefits, nor are so-called "needs assessments" valid or objective instruments for developing such data. See Office of Assistant Secretary for Planning and Evaluation, U.S. Dep't of HEW, Needs Assessment: A Critical Perspective (Dec. 1977) (on file with Yale Law Journal).

Additional complications exist. One is the existence of age-specific programs, see, e.g., 20 U.S.C. $\$ \$ 361.363$ (1976) (services provided elderly readers); 42 U.S.C. $\$ 13950$ (1976) (age 65 eligibility for health insurance programs); of programs that, though not age-specific, tend to focus on particular age groups, see, e.g., id. $\$ \S 601-609$ (Aid to Families with Dependent Children); id. $\$ \$ 1396-1396 j$ (Medicaid); and of private sector mechanisms, such as private health insurance or veterans organizations, that provide similar services or benefits to particular age groups. When these program interactions are taken into account, the impossibility of determining objectively the extent to which, for example, the elderly need and wish to participate in community health, employment, and other federal programs becomes even more evident. Sce pp. 51-52 infra. The difficulties do not end there. Additional difficulties include the methodological problems that confront any effort to draw inferences from age-specific correlations or from comparisons of participation with eligibility, see pp. 50-52 infra; the cost differentials of serving different age groups, see note 221 infra; and the existence of other civil rights requirements directed at characteristics other than age, see note 290 infra. See generally M. Gutowski \& J. KosHeL, Methods for Assessing Age Discrimination in Federal Programs 5-11 (1977) (discussing problems of defining such terms as discrimination on basis of program participation rates). 
race $^{35}$ and sex ${ }^{36}$ differentials is even more problematic with respect to age group differentials. ${ }^{37}$ Unless virtually all facially neutral classifications are to become suspect, the use of non-age factors ought to enjoy a very strong presumption of reasonableness notwithstanding the agespecific differential impacts that inevitably ensue. ${ }^{38}$

The Burden of Justifying Age Classifications. In evaluating the acceptability of age classifications and non-age factors having different impacts upon different age groups, one must consider not only the consequences of using them, but the motives that animated such uses. ${ }^{30}$ Because legislative motive is a notoriously elusive concept, ${ }^{40}$ however, inferences about motives and consequences must inevitably be drawn from the political and social contexts in which these uses arise.

From this perspective, the use of age as a classificatory criterion entails a far smaller risk of arbitrariness and oppression than the use of race, alienage, or other criteria that have been held to exacting standards by the courts. ${ }^{41}$ This is not to say, of course, that certain age groups are never disadvantaged relative to others in the competition for scarce social resources; political conflicts inevitably generate winners and losers. It is only to say that age groups, unlike certain racial and ethnic minorities, ${ }^{42}$ do not come to that competition with any systematic political disability or historical disadvantage that would justify regarding the outcomes as a priori invidious, unreasonable, or suspect. ${ }^{43}$

35. See Washington v. Davis, 426 U.S. 229, 239-45 (1976) (law or act not necessarily unconstitutional solely because of racially disproportionate impact). See generally Fiss, $A$ Theory of Fair Employment Laws, 38 U. CHI. L. REv. 235, 290-310 (197I) (examining difficulties of evaluating impact of facially innocent criteria).

36. See Personnel Adm'r of Mass. v. Feeney, 99 S. Ct. 2282, 2291, 2296 (1979) (veteranspreference statute not violative of equal protection because distinction drawn between veterans and nonveterans was not pretext for gender discrimination); $T$. SowELL, AFFIRMATIVE ACTION Reconsidered 23-34, 39 (1975) (explaining sex-specific differentials in faculty hiring and pay practices as due to nondiscriminatory practices).

37. Given the paucity of age-specific data relative to race-specific and sex-specific data, disproportionate impact may be even more difficult to establish in the case of age, quite apart from differences in the impact of non-age criteria on people of different ages, sexes, and races.

38. See pp. 77-80 infra; cf. Fiss, supra note 35, at 308-10 (arguing facially neutral factors producing disproportionate racial impact should be invalidated only in exceptional cases).

39. See Personnel Adm'r. of Mass. v. Feeney, 99 S. Ct. 2282, 2293 (1979) (though impact provides important starting point, purposeful discrimination is what offends Constitution).

40. See A. Bickel, The Least Dangerous Branch 208-21 (1962); Ely, Legislative and Administrative Motivation in Constitutional Law, 79 YALE L.J. 1205, 1212 (1970).

41. See Ely, The Supreme Court, 1977 Term-Foreword: On Discovering Fundamental Values, 92 HaRv. L. REv. 5, 7-16 (1978) (analyzing judicial treatment of non-age classifications).

42. Massachusetts Bd. of Retirement v. Murgia, 427 U.S. 307, 313-14 (1976) (old age does not define discrete and insular group in need of extraordinary protection).

43. For this reason, the constitutional standards for determining the validity of age classifications are far more permissive than those based upon race. Compare Vance v. 
If age is indeed radically different from race as a basis for distinguishing between people in the distribution of resources, and if the use of non-age factors having disproportionate age-specific impacts is inescapable, then an appropriate conception of age discrimination must possess distinctive contours that acknowledge both of these conditions. Such a conception will necessarily be one of relatively limited reach, leaving decisionmakers free to employ age distinctions and non-age criteria in a wide variety of social choice contexts. If such a result seems difficult to square with the rhetoric of reform in which Congress enveloped the ADA, it remains one that the distinctive nature of age as a classificatory characteristic requires.

\section{The Form of Policy: Two Models of Group Protection}

Broadly speaking, there are two distinctive statutory forms through which the interests of discrete groups can be protected or advanced. Each form proceeds from, or is implied by, a particular definition of the problem to which the statutory policy is addressed; each form, in turn, suggests certain consequences that the policy will tend to generate. I shall call these forms the "nondiscrimination model" and the "allocative model."

The first, of which Title VI ${ }^{44}$ is the purest example, is a command to persons responsible for allocating resources or imposing rules that a particular fact or attribute not be considered in making allocative or regulatory decisions. The second, of which the Older Americans Act ${ }^{45}$ is an example, is a command to such persons that they distribute resources or impose rules according to particular criteria prescribed in the law or to be developed by regulation. These criteria are often defined in terms that affirmatively seek to relate the groups eligible to receive benefits under the statute to the specific social problem or condition that the statute purports to address. ${ }^{40}$ What most clearly distinguishes the nondiscrimination model from the allocative model is the different attitude implicit in each toward the use of particular

Bradley, 99 S. C. 939 (1979) (upholding mandatory retirement age under rational basis test) with Regents of the Univ. of Cal. v. Bakke, 438 U.S. 265, 291 (1978) (Powell, J., announcing judgment of the Court) (racial distinctions inherently suspect and call for most exacting judicial examination).

44. 42 U.S.C. $\$ 2000 d$ (1976).

45. Older Americans Act of 1965, Pub. L. No. 39-73, 79 Stat. 219 (1965) (codified at 42 U.S.C. $\$ \$ 3001-3056(\mathrm{f})(1976)$ ).

46. For example, the eligibility criteria for compensatory-education benefits involve the family income or low cducational achievement of a child, see 20 U.S.C. $\$ 24 \mathrm{Ic}$ (c) (1976), and the eligibility criteria for disability benefits involve income, duration of disability, capacity for gainful employment, and the like, see 42 U.S.C. $\S 1382$ (1976). 
attributes such as age to help shape social choice: the one, at least in its purest "attribute-blind" form, is implacably opposed to such use; the other embraces such a use as a means of defining needs and informing the exercise of discretion.

The origins, features, and implications of each model as "ideal types" are explored fully in Part IV. At this point, two observations will suffice. First, the ADA evidently was conceived of as a hybrid form: while its prohibition of discrimination employs the nondiscrimination model, its reasonableness exceptions contemplate that many allocative choices that take account of age may properly be exercised by decisionmakers. Second, Congress fused the two models without even addressing the fundamental tensions between them; in doing so, it created a policy instrument of uncertain capacity, one with potential for mischief.

\section{The Political Context and Legislative History of the ADA}

This Part begins by briefly tracing the growth in federal legislation advancing the interests of the elderly during the decade preceding the development of the ADA, and documents that the elderly by 1975 constituted a powerful and effective political force. The remainder of Part II chronicles the remarkably scant legislative history of the $\mathrm{ADA}$, and analyzes the Civil Rights Commission report on age discrimination. This analysis reveals that the principal policy-informing organs-Congress, HEW, and the Civil Rights Commission-utterly failed either to lay an adequate conceptual and empirical foundation for the ADA or to consider its legal and policy implications.

\section{A. The Historical and Political Background}

The constitutional system of separation of powers, of checks and balances, of fragmented institutions, and of decentralized sources of power generates enormous political inertia. ${ }^{47}$ That inertia constitutes the chief obstacle to the adoption of new, affirmative social policies. Other political institutions and traditions, such as the party system, patronage, logrolling, and interest groups, overcome this inertia by aggregating disparate sources of power into majority support for new policies. Enactment of such initiatives, however, usually has required

47. See, e.g., R. Neustadt, Presidential Power 33 (1960) (Constitution created govern. ment of separated institutions sharing powers); Note, The Court-Appointed Special Prosecutor: In Quest of a Constitutional Justification, 87 YALE L.J. 1692, 1696 n.21 (1978) (discussing complexities of separation-of-powers question). 
some additional contextual ingredient: a pervasive economic crisis, ${ }^{48}$ an electoral landslide for the presidential party, ${ }^{49}$ a situation in which well-organized interests can benefit through legislation or administrative action imposing diffuse or concealed costs on the general public, ${ }^{50}$ or the ability to define a problem in powerfully symbolic terms. ${ }^{51}$

Several such ingredients combined in the case of the ADA to yield a formidable, indeed irresistible, political offering: it promised benefits to a visible, politically influential group that all Americans hoped some day to join; its sponsors argued that it could confer these benefits at no additional cost; its redistributional implications were not clear, or at least were not noticed; and it was a small and inconspicuous part of a large omnibus bill that both Congress and the administration supported. Perhaps most important, it drew strength from the moral legitimacy and rhetorical force of the civil rights movement of the 1960 's and early 1970 's, a provenance that is critical to understanding how Congress conceptualized and responded to the problem of age discrimination.

By 1975 , the political foundation for the ADA had been laid. In addition to the Age Discrimination in Employment Act (ADEA) and other federal civil rights laws, ${ }^{52}$ many states had adopted statutes prohibiting age discrimination in employment, ${ }^{53}$ housing, ${ }^{54}$ credit, ${ }^{55}$ public accommodation, ${ }^{50}$ or education. ${ }^{57}$ A White House Conference on Aging, held in late 1971, had focused national attention on the needs of the elderly and had recommended changes in governmental policy toward the elderly..$^{58} \mathrm{~A}$ torrent of exposés concerning execrable

48. See, e.g., J. Burns, Roosevelt: The Lion ANd THE Fox 161-226 (1956) (examining Roosevelt's leadership in Great Depression); A. Schlesinger, The Coming of the New DEAL (1957) (same).

49. See D. Kearns, Lyndon Johnson and the American Dream $212-50$ (1976) (landslide victory enabled Johnson to launch Great Society programs).

50. See Wilson, The Politics of Regulation, in Soctal Responsibility AND THE Business Predicament 141-42 (J. McKie ed. 1974).

51. See M. Edelman, The Sxmbolic Uses of Polirics (1964) (discussing role of symbols in politics).

52. See p. 29 supra (discussing civil rights statutes).

53. E.g., Mich. CoMp. Laws ANN. \$ 37.2202 (Supp. 1979); N.M. STAT. ANN. § 4-33-7A (Supp. 1975).

54. E.g., Alaska Stat. $\$ 18.80 .240$ (Cum. Supp. 1978); ConN. Gen. Stat. $\$ 53-35$ (1977).

55. E.g., ME. Rev. Stat. ANN. tit. 5, $\$ 4596$ (1979); OHIo Rev. Code ANN. $\$ 4112.021$ (Page 1977).

56. N.J. Stat. ANN. \$ 10:5-4 (West 1976); N.Y. Exec. LAW \$ 291(2) (McKinney Supp. 1978).

57. E.g., MinN. Stat. ANN. § 363.03 (West Supp. 1979); N.Y. Exec. Law $§ 291(2)$ (McKinney Supp. 1978).

58. 1971 White House Conference on Aging, II Final Report: Toward a National Policy on AGING (recommending numerous changes in domestic policies affecting elderly). See generally R. ButLer, Why SuRvive? Being OLd IN AMERICA 331-34 (1975) (critiquing Conference). 
and often illegal conditions affecting large numbers of elderly people flowed from Congress, state legislatures, and the media..$^{59}$ Perhaps the greatest force behind the development of the $\mathrm{ADA}$, however, was the acceleration of a long-term demographic trend of great political, social, and economic consequence-the steady aging of the American population, ${ }^{00}$ an increase in the number and proportion of elderly Americans that is dwarfed by the growth rates estimated for the future. ${ }^{61}$

If the elderly constituted a powerful political force simply by virtue of their numbers, ${ }^{62}$ their real strength had additional sources including, among other factors, the absence of any consistent opposition to their agenda, their ability to form political alliances, and a strong public image of legitimacy stemming from their status and broad distribution throughout all strata of society. ${ }^{63}$ As Peter Drucker has observed, "[I]n sharp contrast to every other minority group, the older population has a very large constituency outside its own ranks." ${ }^{4} 4$

The elderly translated their political power into a series of formidable legislative achievements. ${ }^{65}$ By 1975 their successes included Medicare and Medicaid, which together pay for over two-thirds of the health-care costs of the elderly; ${ }^{66}$ rapidly rising Social Security benefits

59. See, e.g., Senate Special Comm. on Aging, 93d \& 94th Cong., Nursing Home Care in the United States: Failure in Public Policy (introductory and supporting papers no. 1-7) (Comm. Print 1974-76); R. Butler, supra note 58, at 103-38, 260-99.

60. In 1776 , persons aged 65 or older comprised only $2 \%$ of the nation's population. Brotman, The Aging of America, NAT'L J., Oct. 17, 1975, at 1622. Their share had doubled to $4 \%$ by 1900 , Bureau of CEnsus, U.S. Dep'T of Commerce, I Historical Statistics of THE UNITEd States 15 (1975), and reached $9.8 \%$ by 1970, Statistical Abstract, supra note 21 , at 29 . In mid-1977, the 23.5 million persons aged 65 or older comprised nearly $11 \%$ of the population. Id. at 472 .

61. The 65-and-over group's share of the population is expected to exceed $14 \%$ by 1990 , to increase to $15.6 \%$ in 2020 , and to rise to more than $18 \%$ by $2025-\mathrm{a}$ total of nearly 55 million persons. Statistical ABstract, supra note 21, at 8-9.

62. Because the percentage of elderly persons who actually vote in elections generally exceeds that of other age groups, the elderly population's impact on elections is even greater than their percentage of the population. For example, persons 65 years and over outvoted all age groups under 45 years $(56 \%$ participation versus $53 \%$ for general population) in the November 1978 congressional election. Bureau of Census, U.S. DEP'T OF Commerce, Social and Economic Characteristics of the Population, 1978, at 17 (1979).

63. See H. Pratr, The Gray LobBy 83-85 (1976); J. Tierney, The National Council of Senior Citizens: From the Bingo Circuit to Political Action 29-31 (May 15, 1975) (unpublished manuscript on file with Yale Law Journal) (suggesting reasons for strength of senior-citizens lobby).

64. P. Drucker, The Unseen Revolution 178 (1976). Drucker describes the impending conflict between the economic claims of the elderly and those of other "deserving minorities" and concludes that, "[i]f this clash were to be decided by voting power alone, it would almost certainly be won by the older people. With their support among the middle-aged at work, they could marshal by themselves a near-majority of the voting population." Id. at 181 .

65. See H. Pratr, supra note 63, at 1-2.

66. Brotman, supra note 60 , at 1627 . 
indexed against inflation; ${ }^{07}$ the Supplementary Security Income program, ${ }^{68}$ which established a minimum federal income for the elderly, blind, and disabled and also is indexed against inflation; ${ }^{60}$ special housing programs; ${ }^{70}$ pension reform; ${ }^{71}$ the Age Discrimination in Employment Act of $1967 ;^{72}$ and preferential tax treatment. ${ }^{73}$ Another example of the political effectiveness of the elderly is the extraordinary growth in appropriations under the Older Americans Act of 1965.74 The Act, which authorizes a pastiche of grant programs for services, planning, research, and training, was implemented by appropriations that mushroomed from $\$ 7.5$ million in 1966 to $\$ 245$ million in $1975 .{ }^{75}$ Between 1975 and 1978, the total nearly trebled, reaching $\$ 696.4$ million. ${ }^{76}$ As one observer recently noted, "the aging have proved a difficult group for officials to ignore or 'buy off' with purely symbolic concessions." 77

\section{B. Legislative History of the 1975 ADA}

When the Older Americans Act came up for reauthorization before a subcommittee of the House Education and Labor Committee early in 1975, the subject of age discrimination was not on the agenda. Indeed, the subject was mentioned only once during the hearings-and then almost in passing-when Arthur S. Flemming, the influential HEW Commissioner on Aging, ${ }^{78}$ testified. Responding to a general

67. Between August 1965 and August 1978, the average monthly Social Security benefit awarded to a married worker retiring at age 65 increased from $\$ 123.21$ to $\$ 406.51$, an increase of $230 \%$. Social. Security Bulletin, December 1978, Table M-13, at 43. During the same period, the consumer price index increased by slightly more than $100 \%$. Bureau of Labor Statistics, U.S. Dep't of Labor Monthly Labor Review, August 1979, at 89 .

68. 42 U.S.C. $\$ \S 1381-1383$ (1976).

69. Id. $\$ 1382 \mathrm{f}$.

70. See, e.g., 12 U.S.C. $\$ 1715 \mathrm{~V}$ (1976) (providing federal mortgage insurance for housing for elderly). The elderly also benefit disproportionately from the low-rent public housing program. See Gurowski \& Koshell, supra note 34, at 41-61.

71. See Employee Retirement Income Security Act of 1974, Pub. L. No. 93-406, 88 Stat. 829 (1974) (codified in scattered sections of 26, 29 U.S.C. (1976)) (protecting employee benefits).

72. 29 U.S.C. $\$ \$ 621-634$ (1976).

73. See, e.g., I.R.C. $\$ 37$ (retirement income credit); $i d$. $\$ 121$ (reduced tax on gain from sale or exchange of residence of elderly individual).

74. Pub. L. No. 89-73, 79 Stat. 219 (1965) (codified at 42 U.S.C. $\$ \S 3001-3056 f$ (1976)).

75. See S. REP. No. 255, 94th Cong., 1st Sess. 14 (1975), reprinted in part in [1975] U.S. Code Conc. \& AD. News 1252, 1255 [hereinafter cited as S. Rep. No. 255 with citations to pages in original Report].

76. See S. REP. No. 855, 95th Cong., 2d Sess. 3 (1978) (listing appropriations under Older Americans Act).

77. H. Pratr, supra note 63, at 83 .

78. Dr. Flemming was then also Chairman of the United States Commission on Civil Rights and had been Secretary of Health, Education, and Welfare in the 1950's. One 
question, Flemming denounced "ageism," equating it with "racism" and "sexism,"79 and expressed the "hope that the day will come when the Civil Rights Act will be amended to include age . . . as one of the factors that must be taken into consideration under the Civil Rights Act." 80

Dr. Flemming's suggestion fell on fertile soil. Bills quickly were introduced in both the House and Senate ${ }^{81}$ to amend the Older Americans Act to prohibit discrimination on the basis of age in federally assisted programs, subject to several broad exceptions. ${ }^{82}$ The House committee reported the bill on March 14, 1975, but apart from some rhetorical flourishes the report was silent on the meaning of the bill's vague language. ${ }^{83}$

Throughout this period, the Administration was not asked for its views on the age discrimination legislation. ${ }^{84}$ Desperate to slow the

student of the political achicvements of the "modern senior movement" has underscored Flemming's role: "Flemming's extraordinary stature cannot be emphasized too strongly. One would have difficulty naming another subcabinet level official whose influence extended into the Oval Office of the White House and who has been in a position, as is reliably reported, to more than once head off a threatened veto by contacting the President directly." H. Pratr, supra note 63, at 217.

79. The term "ageism" apparently had been coined by Dr. Robert Butler. See R. ButLER, supra note 58 , at 11 .

80. HOUSE REPORT, supra note 13 , at 15 .

81. See S. 1425, 94th Cong., 1st Sess. (1975) (introduced March 17), summarized in S. ReP. No. 255, supra note 75, at 1; H.R. 3922, 94th Cong., 1st Sess., reprinted in 121 Cong. Rec. 9204-10 (1975) (introduced Feb. 27). The bills apparently were drafted by the subcommittee staff. Telephone interview with Stephen Kurzman, former Assistant HEW Secretary for Legislation (May 29, 1979) (notes on file with Yale Law Journal).

82. The principal exceptions appeared in H.R. 3922, 94th Cong., Ist Sess., $\S 303(\mathrm{~b})$, reprinted in 121 CoNG. REc. $9204-10$ (1975).

83. In its report, the committee simply shared Dr. Flemming's wish "for the nation to combat ageism," asserting that "[n]on-involvement of older persons is traceable time and again ... to a determination by the leaders of many institutions in our society to discriminate against persons as workers and as volunteers solely because they have reached a given age. They refuse to consider the merits of each case. In so doing they reflect ... a deep-seated prejudice against the elderly." House REPORT, supra note 13, at 15. The Report contended that older persons had not been provided "services which we believe other age groups are entitled to as a matter of right," that the elderly had not received "their fair share of services in such areas as health and transportation," and that "[i]t is clear ... that discrimination against older persons is still widespread." Id. at 15-16. The Report cited no evidence to support its allegations of pervasive age discrimination.

84. Dr. Flemming's earlier remarks, having been made in response to a question rather than in prepared testimony, had not been cleared by HEW and could not have represented the Administration's position. The lack of clearance was evident from subsequent department efforts to head off the legislation, see pp. 44.47 infra, and was confirmed by the official then responsible for securing HEW clearance of testimony, Telephone interview with Stephen Kurzman, supra note 81. Reflecting the Administration's concern over the lack of input, HEW Secretary Weinberger, whose department's programs would be most affected by the bill, wrote House Minority Leader John Rhodes on March 20 to complain that HEW had not been given an opportunity to address the age discrimination issue during the hearings. Letter from Caspar W. Weinberger to John Rhodes 
legislative juggernaut, HEW representatives met with subcommittee Chairman John Brademas and his staff to urge caution and to determine what had prompted the committee action, but were unceremoniously rebuffed. ${ }^{85}$ Debate on the bill contained virtually no discussion of the age discrimination provisions, ${ }^{86}$ and H.R. 3922, with the age discrimination section unchanged, passed the House. ${ }^{87}$

Having been ignored and then rebuffed in the House, HEW turned its attention to the Senate, where hearings had barely touched upon the age discrimination provisions. ${ }^{88}$ In a May 9 letter to the Senate committee overseeing the bill, the department urged that "Congress not act precipitously" 89 but instead seek more information

(March 20, 1975), reprinted in 121 CoNG. REc. 7915-16 (1975). Weinberger suggested that the committee bill raised a number of problems and urged that before taking further action, the committee refer the age discrimination issue to the Federal Council on Aging for its consideration. Id.

85. HEW officials were told that Dr. Flemming had asked for the legislation. When they asked what evidence of discrimination justified such action, they were told only that a number of medical schools barred older persons from applying. Telephone interview with Stephen Kurzman, supra note 81.

86. Only two congressmen ever addressed the meaning of the age discrimination legislation. Congressman Brademas repeated almost verbatim the committee report language, noting with approval Dr. Flemming's assertion that ageism is as great a problem as racism or sexism. 121 Conc. Rec. 9212 (1975). He then noted the effect of the ADA on mandatory retirement plans and apprenticeship programs. Id. Congressman Quie provided the only other comment. See 121 Conc. Rec. 37,299 (1975) (remarks of Rep. Quie) (interpreting statutory exceptions to allow what amount to cost effectiveness concerns to affect legal rights under $A D A)$.

87. 121 Conc. Rec. 9251 (1975). The bill passed under the "suspension of the rules" procedure, usually reserved for noncontroversial legislation.

88. The only extended discussion of age discrimination arose in testimony by Dr. Flemming. He contended that the elderly were underrepresented in a variety of federally assisted programs, citing in support comparisons of the program participation rates of those over age 65 with their share of the general population in the program's service area. He reiterated the statement that he made in the House hearings, that there was a need to combat ageism through civil rights legislation. See Legislation to Extend the Older Americans Act: Hearings Before the Subcomm. on Aging of the Senate Comm. on Labor and Public Welfare on S. 1425 94th Cong., Ist Sess. 390-91, 396-98 (1975) (testimony of Arthur S. Flemming) [hereinafter cited as 1975 Senate Hearings]. A brief colloquy also occurred regarding application of the ADA to age-limited medical school admissions policies.

Several other witnesses addressed age discrimination provisions, but only briefly. One urged that the exceptions provisions be eliminated entirely. Id. at 403 (testimony of Cyril F. Brickfield). Another urged that the protections of the bill extend only to the elderly. Id. at 486, 507 (testimony of Jack Ossofsky). A third urged that only the exception for programs or activities "established under authority of any law" be retained. Id. at 561.62 (testimony of Richard Hamilton). Two other witnesses, Senators Church and Bentsen, merely indicated general support for the age discrimination provisions. Id. at 375 (statement of Sen. Church); id. at 377 (statement of Sen. Bentsen).

89. The letter noted that a preliminary review had indicated the bill "would raise administrative issues and questions similar to those raised by Title IX," and pleaded for more time to explore the bill's "potential ramifications." Letter from Stephen Kurzman to Harrison A. Williams, Chairman, Senate Comm. on Labor and Public Welfare (May 
from affected agencies. A month later, however, the Senate subcommittee approved a bill almost identical to the bill that passed the House. ${ }^{90}$ HEW Secretary Caspar Weinberger then wrote the full committee to "expand upon" his May 9 letter. ${ }^{91}$ Again stressing that the House bill raised many complex issues, he warned that it "would leave to the Executive Branch ... momentous policy decisions in wholly uncharted areas without the benefit of any specific legislative guidance." 92 Focusing upon the exceptions in the House bill, which spoke in terms of "reasonable" uses of age and "reasonable" factors other than age, the Secretary posed a series of questions about their meaning, ${ }^{93}$ questions to which Congress never responded.

The Secretary's warning found a responsive audience in the Senate committee. When the committee reported its bill to the floor on June 25, the age discrimination title did not contain the nondiscrimination provision that the subcommittee and the House had approved. ${ }^{94}$ In-

9, 1975), reprinted in S. REP. No. 255, supra note 75, at 35-37. The Department of Transportation wrote the committee to concur in HEW's position. Letter from Rodney E. Eyster, General Counsel, Dep't of Transportation, to Harrison A. Williams (May 8, 1975), reprinted in id. at 41.43 .

90. S. Rep. No. 255, supra note 75, at 13 . The only significant change made by the Senate subcommittee was inclusion of a specific exemption for any employment practices subject to the ADEA.

91. Letter from Caspar W. Weinberger to Harrison A. Williams (June 18, 1975), reprinted in id. at 37.

92. Id.

93. Weinberger stated:

Neither the bill nor its legislative history indicates what factors would be "reasonable." Even a very preliminary review of the potential ramifications suggests a myriad of unexplored issues such as the following:

Is it "reasonable" for school systems to exclude three-year-olds from kindergarten classes? Or eleven-year-olds from high school classes?

Can a medical or dental school bar a 50-year-old person from taking one of its limited classroom seats because his or her life expectancy suggests a practice of relatively brief duration?

It is "reasonable" to limit reduced-fare or free public transportation to those age 65 or over?

Can existing guaranteed housing loans and senior citizen housing programs be limited to specific age groups?

At what age would a person be deemed to be sufficiently mature to consent to sterilization, to receive family planning information or to elect specific medical treatment?

Id. at 37-38. Weinberger closed with a renewed plea for "a reasonable interval to explore and resolve such issues as I have outlined above before formulating an Age Discrimination Act." Id.

94. On the Senate floor, Senator Eagleton explained that the committee had been influenced by "the seriousness of the concerns expressed" in Secretary Weinberger's letter. 121 Cong. Rec. 21,172 (1975). Senator Beall added that "the committee did not feel that a sufficient body of data was available for us to adequately structure effective legislation to address this problem. The I-year study by the Civil Rights Commission should remedy this situation and enable us to address ourselves to this pressing social problem." Id. at $21,174$. 
stead the bill mandated a one-year study of age discrimination by the U.S. Commission on Civil Rights. ${ }^{95}$ The committee explained why it wanted to defer age discrimination legislation until the study's completion:

When the results of the Commission's study are available, the Congress will have for the first time a thorough analysis of the causes, scope, nature, and extent of age discrimination in federally assisted programs. At that time, the need for additional legislation on this subject can be fairly and reasonably assessed.90

The Senate passed the amended bill, and a conference with the House on the age discrimination provision ensued. ${ }^{9 \tau}$

In October 1975, with the congressional session drawing to a close and a presidential election year approaching, the conference on the Older Americans Act Amendments remained deadlocked. Anxious to reach some accommodation that would reauthorize the department's programs but reluctant to complicate delicate negotiations being conducted within a Congress not notably friendly to the Administration, HEW officials informally circulated to the conference committee staff an internal HEW memorandum analyzing a conference draft bill that combined the House bill with a mandate for a Civil Rights Commission study.$^{98}$

This memorandum discussed issues raised by the conference draft, especially the extreme ambiguity of the exceptions and the lack of direction given the Commission for its study of age discrimination. The memorandum suggested that enumerating specific activities intended to be rendered illegal might be a more sensible approach, but acknowledged that it probably was impractical "at this late date, and in Conference." 99 It concluded by reemphasizing the difficulty of predicting what the sweeping but vague prohibition on age discrimination ("this potential nightmare") ${ }^{100}$ might mean in practice. Other than the

95. See S. REP. No. 255, supra note 75, at 31 .

96. Id. at 32 .

97. See 121 Cong. Rec. 21,833 (1975); cf. id. at 37,735 (remarks of Sen. Eagleton) ("The effort to resolve the difficult issues posed by the age discrimination provisions of the House bill was responsible for the delay of several months in reaching agreement on the entire bill in conference. All other disputed issues were settled last July.")

98. See Memorandum from Ira Goldstein to Bill Morrill, HEW Assistant Secretary for Planning and Evaluation (Oct. 25, 1975) (on file with Yale Law Journal) [hereinafter cited as Memorandum]. This memorandum was the first, and apparently only, analysis by HEW staff of the program and policy implications of the ADA. Telephone interview with Bill Morrill (May 9, 1979) (notes on file with Yale Law Journal).

99. Memorandum, supra note 98 , at 11 .

100. Id. 
Weinberger letters (which only raised questions and urged caution) and several meetings between HEW officials and committee personnel (which avoided specifics), this internal memorandum-written hastily and under the constraint of a fait accompli-constituted the only substantive contribution that the Executive Branch, which alone possessed the detailed knowledge of program operations needed to inform the debate, was to make to the design of the original Act.

When the conference report was filed on November 17, it was clear that the House had prevailed: the age discrimination study mandated by the Senate bill was included, but it would be conducted after the $\mathrm{ADA}$ had been enacted into law (although prior to its effective date). ${ }^{101}$ Legislation was not to be deferred during the pendency of the Commission's study, but the significance of the study "to a final resolution by the Congress of the difficult policy issues that are left undecided by this legislation" was emphasized.102

101. The conference substitute-which became the ADA of 1975-made six notable changes in the House bill. First, it made clear that the bill was intended to prohibit only "unreasonable" age discrimination, a change that clarified little. The Conference Report noted that this meaning was already implicit in the exceptions, which constitute "considerations of reasonableness." CONFERENCE REPORT, supra note 9, at 56 ("there is not a clear consensus among the conferees" on what uses of age would be reasonable). The mandate to the Civil Rights Commission also was altered to require a study of "unreasonable age discrimination." Id. at 57 . Second, the exception for any action that "reasonably takes into account age as a factor necessary to the normal operation" of a federally assisted program was expanded by adding the clause "or to the achievement of any statutory objective of such program or activity." 42 U.S.C. $\S 6103(\mathrm{~b})(1)(A)(1976)$. The Conference Report stated only that this change was intended "to clarify congressional intent." Conference Report, supra note 9, at 58. Third, the exclusion for any program "established under authority of any law" that provides age-conditioned benefits was expanded. The change included in the exclusion those programs for which participation was prescribed in age-related terms, such as "older Americans," "elderly," or "children." 42 U.S.C. § 6103(b)(2) (1976).

Fourth, the exclusion of employment practices was clarified. Conference REPORT, supra note 9 , at 58. This provision is now codified at 42 U.S.C. $\$ 6103(c)$ (1976). Fifth, the conference deleted both the authority of the Attorney General to bring "pattern or practice" actions and the private cause of action contained in the House bill, providing instead that fund termination and other means available to the federal agencies to enforce their regulations would be the exclusive remedy under the ADA. ConfERENCE REPORT, supra note 9, at 57. A private cause of action was added to the ADA in the 1978 Amendments. Finally, the conference prescribed a schedule for the Civil Rights Commission study, the issuance of general, governmentwide regulations by HEW, and the issuance of agency-specific regulations by each federal department. 42 U.S.C. $\$$ 6103(a) (1976). In the 1978 amendments, the prior effective date was changed from January 1 , 1979, to July 1, 1979. The schedule was designed so that the Commission's study, the agency responses to it, and any proposed regulations could be considered in 1978, when the Older Americans Act would again be up for reauthorization. CONFERENCE REPORT, supra note 9, at 57. The conference also provided more direction for the Civil Rights Commission study, prescribing general procedures to be observed and issues to be addressed. Many of these specifications had been suggested in the internal HEW memorandum of October 25. See Memorandum, supra note 98, at 7-10.

102. Conference Report, supra note 9, at 59. 
The House debate on the conference report was perfunctory and only two remarks are of interest: Congressman Brademas's assurance that the ADA could provide "substantial additional services and benefits to the elderly without establishing a single new program or requiring additional program funding," 103 and Congressman Quie's interpretation of the statutory exceptions to permit what amount to cost effectiveness considerations to affect legal rights under the $\mathrm{ADA},{ }^{104}$ an issue that remains central in interpreting the Act. ${ }^{105}$ Senate debate on the conference report was equally desultory, with one important exception: Senator Eagleton posed several fundamental questions about the meaning or possible implications of the $A D A,{ }^{100}$ questions that appear nowhere else in the entire legislative history of the Act and that were never answered. Despite his misgivings, however, Eagleton "reluctantly" supported the conference report. ${ }^{107} \mathrm{He}$ and others did so on the premise that although "the evidence and background data were lacking to make effective supportable decisions in this very complicated area," 108 the forthcoming Commission study would fill this void by alerting Congress to imperfections in the statute. Indeed, this consideration was vital to the conference compromise, as the conference report makes clear ${ }^{109}$ and as the President stated upon signing the

103. See 121 Cong. Rec. 37,297 (1975).

104. Id. at 37,299 (1975). Representative Quie also pointed out that the bill had been amended to reject the "infection theory," under which discrimination in activities not receiving federal funds could be reached so long as the entity received federal assistance for some activity. $I d$.

105. See pp. 70-79 infra.

106. Addressing his colleagues, Senator Eagleton said:

I could never get satisfactory answers to certain fundamental questions, such as: "Which programs? In what numbers? Who decides what age discrimination is unreasonable?"

This last question of reasonableness is of the utmost importance, Mr. President, for unlike race discrimination, age discrimination is not per se arbitrary. Our laws commonly make distinctions among individuals based upon their age, often for the purpose of defining those eligible for a particular kind of Government benefit, such as social security, or for describing the target group for a particular piece of legislation, just as this bill is designed to aid older Americans. So it is not all age discrimination that we want to prohibit, but only that which is unreasonable.

And what is unreasonable age discrimination? Whatever it is cannot be determined from the bill, for it simply prohibits "unreasonable age discrimination" and tosses the ball to the executive branch to determine what is reasonable and unreasonable. 121 Conc. Rec. 37,735 (1975). Senator Cranston echoed Eagleton's concern about the lack of evidence to support the ADA, but his remarks were more general. See id. at 37,748.

107. See id. at 37,735 (remarks of Sen. Eagleton). He did so only because agreement was essential to prevent expiration of the Older Americans Act programs, the Civil Rights Commission study might "provide guidance on the policy issues left unresolved," and Congress would have an opportunity to review regulations under the ADA before they became effective. See $i d$.

108. See id. at 37,748 (remarks of Sen. Cranston).

109. See Conference Report, supra note 9 , at 59 . 
legislation. ${ }^{110}$ In any event, the compromise had the intended effect; the Older Americans Act Amendments of 1975, containing the ADA, quickly passed both chambers ${ }^{111}$ and was signed into law. During the entire legislative journey of the ADA, only one legislator, Senator Eagleton, had bothered to raise important questions about its meaning.

\section{The Civil Rights Commission Report on Age Discrimination}

If Congress counted on the Civil Rights Commission's study to provide persuasive evidence post hoc for its decision to enact a statute that it had not troubled to think much about, it had reason to be disappointed when the Commission released its study in January 1978.112 The study and recommendations are important, however, for three reasons. First, the study remains the only one purporting to address the nature and extent of age discrimination in a wide range of federally assisted activities. ${ }^{113}$ Second, Congress had stressed that the study would be "essential to a final resolution by the Congress of the difficult policy issues that are left undecided by this legislation." 114 In fact, the House held hearings on the Commission's report as soon as it was released, and adopted its most far-reaching recommendationthe elimination of the reasonableness exceptions. Although this recommendation was deleted in conference, other Commission recommendations were actually enacted. Third, the Commission report, because it implicitly and unqualifiedly adopted the analogy to race discrimination and apparently influenced Congress, contributed significantly to the conceptual confusion that continues to underlie the ADA.

The Commission study began by devising an extraordinarily broad definition of age discrimination-"any act or failure to act, or any law or policy that adversely affects an individual on the basis of age."115 This definition suffered from at least two crucial flaws. First, it lacked the basic attribute of a definition-boundaries. Virtually

110. 11 Weekly Comp. of Pres. Doc. 1326 (Dec. 1, 1975). President Ford was dismayed that " $[t]$ he delineation of what constitutes unreasonable age discrimination is so imprecise that it gives little guidance in the development of regulations to prohibit such discrimination." Id. He expressed hope that the Commission study would permit "these issues to be discussed thoroughly." Id. at 1327.

111. See 121 Conc. REc. $37,301,37,752-53$ (1975) (conference report passed House 404 to 6 and Senate 89 to 0 ).

112. U.S. Comm'N on Civil Rights, I The Age Discrimination Study (1977) [hereinafter cited as I Age Discrimination Study].

113. The study by Gutowski and Koshel examined only two federal programs. M. GuTowski \& J. Koshel, supra note 34, at 11-61.

114. Conference RePort, supta note 9, at 59 .

115. I AgE Discrimination Study, supra note 112, at 2. Although it described this definition as "tentative," $i d$., the Commission has never revised that definition. 
any action by any recipient of federal assistance will affect different age groups differently and thus affect some of them adversely "on the basis of age." 116 Second, it ignored the ADA itself and the limiting concepts embedded in the statutory scheme. The Commission's definition, unlike that implicit in the ADA, elided any notion of reasonableness, ${ }^{117}$ any concession to the "normal operation" of a program or the "objective" of a statute, ${ }^{118}$ or any recognition of the difference between an "action" and a "failure to act."119 Proceeding from this essentially all-inclusive definition of age discrimination, the Commission concluded that in each of the ten federal programs studied, ${ }^{120}$ such discrimination was "widespread,"121 that "persons aged 65 or over are consistently adversely affected," 122 and that "reasons offered by administrators to justify their policies and practices are not acceptable."123

Because the Commission's analysis of age discrimination in the Community Mental Health Centers (CMHC) program is typical of its analyses of the other programs, and because the Commission regarded the CMHC program as "one of the most glaring examples" of age discrimination, 124 that analysis merits closer scrutiny.

Commission's Analysis of the Community Mental Health Centers Program. The Commission's conclusion regarding the CMHC program was a product of essentially the following chain of reasoning: (A) Although $9.9 \%$ of the population in 328 CMHC service areas during 1975 were 65 years of age or older, only $4.1 \%$ of the new patients at those CMHC's were in the 65-or-over age group; ${ }^{125}$ similarly, only $5 \%$ of staff hours for CMHC consultation and education were directed

116. See note 33 supra (giving examples of such programs).

117. See 42 U.S.C. $\$$ 6103(b) (1976) (setting out reasonableness exception).

118. See $i d$. $\$ 6103(\mathrm{~b})(1)(\mathrm{A})$ (defining reasonableness in part by these terms).

119. See id. $\$ 6103$ (b) (referring to "any action otherwise prohibited by the provisions of section $\left.6102^{\prime \prime}\right)$.

120. The programs were the Community Mental Health Center program, the Legal Services program, the Vocational Rehabilitation Basic Grants program, the Community Health Centers program, the Title XX Social Services program, the Comprehensive Employment and Training Act program, the Food Stamp program, the Medicaid program, the Vocational Education basic grants program, and the Adult Basic Education program. The Commission also studied admissions policies for higher educational institutions. See I Age Discrimination Study, supra note 112, at 3-4.

121. Id. at 2.

122. Id.

123. Id. In reaching its judgment, the Commission had available a report, prepared under a Commission contract, that was concerned exclusively with the problems that a broad definition would create. See M. GuTowski \& J. Kosher, supra note 34, at 5-10. The report and its warnings were apparently ignored by the Commission. See U.S. Comm'N on Civil Rights, II The Age Discrimination Study 2-13 (1979) (describing study's methodology) [hereinafter cited as II Age Discrimination Study].

124. I Age Discrimination Study, supra note 112, at 6 .

125. Id. at 7 . 
to agencies dealing with older persons; ${ }^{126}$ (B) Some studies show that the elderly experience certain mental problems at a higher rate than certain other age groups; ${ }^{127}$ (C) Some mental health professionals reportedly preferred to work with younger patients; ${ }^{128}$ there was often a shortage of staff specially trained to serve the elderly; ${ }^{129}$ special outreach efforts to the elderly were often inadequate; ${ }^{\mathbf{1 3 0}}$ and some centers in allocating resources among age groups took into account that the elderly had access to other mental health services. ${ }^{131}$ Therefore, (D) the CMHC program discriminated on the basis of age. ${ }^{132}$

The Commission recognized in its follow-up volume, issued one year later, that a methodology essentially comparing gross program participation rates for various age groups against that group's share of the total population in the service area could not, without more, support a finding of discrimination. ${ }^{133}$ Yet in its more highly publicized initial report, that was precisely the method employed. Nowhere did the Commission define critical concepts, such as "underrepresented" or "need for services." In no instance did it discuss any factor other than discrimination that might explain the "underrepresentation." Given its all-inclusive definition of age discrimination, ${ }^{134}$ of course, these omissions are not surprising: any factor that might explain the "underrepresentation" of the elderly also would fall within its definition of age discrimination.

Setting aside the Commission report, however, it would appear that several factors, taken singly or in combination, are fully adequate to explain this "underrepresentation" without resort to a finding of discrimination; none would fall within any definition of age discrimination that was consistent with the provisions of the ADA. First, the Medicare program, the principal source of payment for the health care received by the elderly, does not accord provider status to CMHC's and thus does not reimburse patients for most CMHG services. ${ }^{135}$ The

126. Id.

127. R. ButLeR, supra note 58, at 227 ("those over age 65 are the most susceptible to mental illness"). Butler perceived widespread age discrimination in the mental health ficld. $I d$. at $225-59$.

128. I Age Discrimination Study, supra note 112, at 36-37; cf. II Age Discrimination STUDY, stupra note 123 , at $84,98-100$ (using similar reasoning to arrive at same conclusion regarding CMHC services to children under 15).

129. I AGE Discrimination STUDY, supra note 112 , at 37 .

130. Id. at 27-30.

131. Id. at 35-36.

132. Id. at 6 .

133. II Age Discrimination Study, supra note 123 , at 6 .

134. See pp. 49-50 supra.

135. See 42 U.S.C. $\$ 1395 \times$ (u) (1976) (defining provider of services as hospital, skilled nursing facility, home health agency or fund); Sharfstein, Will Community Mental Health Survive in the 1980's? 135 AM. J. Psxch. 1365, 1369 (1978) (no CMHC's are certified as providers under Medicare and many are excluded under Medicaid). 
same is true of most private insurance programs. ${ }^{136}$ These coverage limitations reflect a widespread restriction on reimbursement of mental health services in general and outpatient services in particular, ${ }^{137}$ one that may well constitute unwise public policy ${ }^{138}$ But surely it is a restriction that falls well outside any definition of age discrimination that is not simply coterminous with "disproportionate impact."

Second, the elderly are notoriously reluctant to use mental health services voluntarily, a reluctance that contrasts with their high utilization of other medical services ${ }^{\mathbf{1 3 9}}$ and that appears to persist even when broad outpatient benefits are available. ${ }^{140}$ Many of these factors are regrettable, some are not limited to the elderly, and some may even be remediable. Nevertheless, they cannot-with the possible exception of the preference of some providers for younger patients-reasonably be described as age discrimination.

The Commission's Recommendations. The Commission report regarded as age discrimination every policy, practice, action, or inaction that appeared to be correlated with a less than "fair share" 141 of services

136. L. Reed, Health Insurange and Psychiatric Care (1972). On the other hand, Medicare and Medicaid do reimburse for inpatient services in mental hospitals, psychiatric wards of general hospitals, and nursing homes. Thus, while the elderly may be "underrepresented" in CMHC's, they are probably "over-represented" in mental hospitals and nursing homes.

Under Medicaid, states have the option of covering persons over age 65, but not persons between the ages of 22 and 64 , for care rendered in mental institutions, including hospitals and nursing homes. 42 U.S.C. $\$ 1396(a)(10)(1976)$. As of early 1979, 41 states had exercised that option. Telephone interview with Morton Albert, M.D., Acting Director, Division of Mental Health Service Programs (March 1979) (notes on file with Yale Law Journal).

137. Sharfstein, supra note 135 , at 1367-69.

138. For a survey of arguments on both sides of the issue, see U.S. DEP'T OF HEW, Report Required by P.L. 95-210 on the Advantages and Disadvantages of Extending Medicare Coverage to Mental Health, Alcohol and Drug Abuse Center (1978) [hereinafter cited as HEW REPORT].

139. See Goldensohn, Cost, Utilization, and Utilization Review of Mental Health Services in a Prepaid Group Practice Plan, 134 AM. J. Psych. 1223 (1977).

140. See Hustead and Sharfstein, Utilization and Cost of Mental Illness Coverage in the Federal Employees Health Benefits Program, 1973, 135 AM. J. Psצch. 315 (1978). According to one gerontologist, this resistance extends to social services generally. $R$. Burler, supra note 58, at 165-67. Researchers attribute this reluctance to a variety of factors in addition to the economic one: the stigma that often attaches to mental illness, mistrust by the elderly of mental health professionals, a tendency of the elderly to define problems in physical rather than psychological terms, preference for emotional support from family, clergy, or senior citizens groups, lack of transportation, limitations on mobility, fear of visiting new settings, language differences between the elderly and many CMHC staff, and a preference by some mental health providers for better educated, therapeutically promising, and middle-class patients. See id. at 229; HEW REPORT, supra note 138, at 28-31 (citing research studies).

141. Although "fair share" is never defined, the Commission report implicitly employs this definition throughout and explicitly adopts it as the performance goal for affirmative action. See I Age Discrimination Study, supra note 112, at 46-47; II Age Discrimination 
for the elderly. Although this approach begs all of the important questions-for example, questions of differing needs among different age groups, of defining the service appropriately, of causality, and of intent-the Commission report used this bluntest of analytical instruments to strike at a welter of policies and practices that it felt did not adequately serve the elderly. ${ }^{142}$ Yet almost all of these appear to be bona fide (albeit flawed and often ineffective) efforts by decisionmakers to accommodate conflicting policy objectives to limited resources, rather than instances of age discrimination.

Armed with its indictment, the Commission report proceeded to recommend sweeping amendments to the still-unimplemented ADA. ${ }^{143}$ While most of the suggested changes were not major, the Commission's first and most important recommendation certainly was: ${ }^{14 t}$ in order to expand the sweep of the ADA, the Commission would amend the statute's statement of purpose to prohibit all age discrimination and not merely "unreasonable" discrimination, eliminate all "reasonableness" exceptions and the "any law" exclusion, and permit only two narrow exceptions to the flat prohibition against age discrimination. ${ }^{145}$

This recommendation could hardly have been more far-reaching. It would vastly broaden the limited definition of age discrimination implicit in the exceptions and exclusions of the ADA, thereby ignoring most of the differences between age and race as a basis for classification. Among the laws, policies, and practices that might well fall to the Commission's meat-axe were: minimum age laws for obtaining a driver's

STUDY, supra note 123 , at 5-6. While the Commission recognized that in theory "explanations or reasons for the existence of disparities" might invalidate this definition, id. at 6, it failed to discuss such explanations or reasons. For additional complications that arise from application of such a concept to the elderly, see pp. 32-37, 51-52 supra and especially notes 33 \& 34 supra.

142. Singled out as examples of discrimination were the emphasis in some health programs on preventive health care for children, youth, and pregnant women, I AGE. DisCrimination STUDY, supra note 112, at 15-16; the emphasis in the Vocational Rehabilitation program on placement in competitive employment, id. at 16-17; the emphasis in some states' social service programs on protective services for children and families, id. at 21-22; and similar judgments as to program priorities.

143. Id. at 44-51.

144. See $i d$. at $41-44$.

145. Id. at 44. The exceptions would be for any action "specifically directed or provided by the terms of a Federal statute" that provided age-conditioned benefits or cstablished age-related criteria for participation, and for affirmative action. Id. The exceptions extend to any "action taken to overcome the effects of conditions which resulted in limiting participation by persons of a particular age . . ." Id. at 43. Since numerous actions, including those condemned by the Commission, are taken to overcome conditions which limit participation by some age group, this exception appears to be quite broad. It is clear, however, that the Commission wished to except only a narrow category of actions (such as outreach efforts) designed to overcome conditions that limited an age group's participation to a level below the "fair share" for that group. Id. at 43-44. 
license; tax relief for elderly property orwners or special tax exemptions or deductions for the elderly; state juvenile justice systems; minimum age laws for engaging in certain "adult" activities, such as consensual sexual relations, possessing firearms, attending $\mathrm{X}$-rated films, and entering bars; a day-care center's policy of not admitting infants under a certain age; the practice of maintaining separate sports leagues or recreational facilities by age; concentrating screening for certain diseases such as breast cancer on particularly susceptible age groups; and targeting antismoking campaigns towards teenagers. ${ }^{146}$ Moreover, the validity of countless non-age factors would be called into serious question by the changes. ${ }^{147}$

Clearly, no one (and certainly not the Commission, which did not even trouble to ask) knows exactly what laws, policies, and practices this recommendation would invalidate or place in jeopardy. Quite apart from uncertainties of statutory interpretation, ${ }^{148}$ considerable difficulties would arise because no inventory of the age and age-related listinctions or the differentiating factors other than age actually used in federally assisted programs has ever been compiled, much less analyzed for consistency with the ADA. ${ }^{149}$ Significantly, the report shows no evidence that the Commission ever seriously considered either the arguments against repealing the "reasonableness" exceptions and narrowing the "any law" exclusion, or the implications of so sweeping an action. ${ }^{150}$

146. See U.S. Dep't of HEW Fact Sheet on the House-Passed Age Discrimination Amendments (Title IV of H.R. 12255) (1978) (on file with Yale Law Journal) [hereinafter cited as HEW Fact Sheet]. One can never be certain, of course, how a court would construe the Commission's proposed exceptions. But a combination of factors-the legislative intent that could be inferred from Congress's deletion of the word "unreasonable" from the ADA's statement of purpose, the breadth of the prohibition's wording, the specificity of the remaining exceptions, and the principle that civil rights prohibitions are remedial provisions that should be broadly construed-lend support to predictions that such laws, policies, and practices would be in serious jeopardy unless they somehow could be construed to qualify for the Commission's proposed affirmative action exception.

147. This is true because the Commission, in deleting the reasonableness exceptions in the ADA, I AGE Discrimination STUDY, supra note 112, at 43, also would delete the exception for any action that makes a "differentiation [that] is based upon reasonable factors other than age." 42 U.S.C. $\$ 6103(\mathrm{~b})(\mathrm{l})(\mathrm{B})(1976)$.

148. For discussion of the uncertainties of interpretation of the ADA, see Part III infra. For discussion of some uncertainties of interpretation of the Commission's proposed provisions, see note $145-46$ supra.

149. HEW's governmentwide regulations require that such an inventory be conducted for the first time. 44 Fed. Reg. 33,777 (to be codified at 45 C.F.R. $\$ \$ 90.32, .34$. It probably will not be completed until at least two years after the publication of final agency-specific regulations, that is, until late 1981 at the earliest. Id. at 33,777-78.

150. Its discussion of the policy considerations that militate in faror of retaining those exceptions, I AGE Discrimination STuDy, supra note 112, at 39-40, is cursory, conclusory, and simplistic. The Commission neglected entirely to discuss such considerations as the ubiquity, reasonableness, and essentiality of the widespread use of factors other than age. 


\section{The 1978 Amendments to the ADA}

Despite the defects of the Commission's report and recommendations, the House of Representatives embraced them with enthusiasm. Ten days after the Commission released its age discrimination study, a House subcommittee held hearings on the study in connection with the reauthorization of the Older Americans Act. ${ }^{151}$ Shortly thereafter, the House Education and Labor Committee unanimously reported H.R. 1225, the Comprehensive Older Americans Act Amendments of 1978 , to the floor. Contained in the bill were the major amendments to the ADA recommended by the Commission..$^{152}$ Although the merits of these amendments had not been analyzed in the hearings and were not discussed either in the committee report or in floor debate, they quickly passed the House, 361 to $6 .{ }^{153}$ The Senate, meanwhile, had not held hearings on amendments to the ADA but had passed a bill reauthorizing the Older Americans Act. ${ }^{154}$ The House and Senate bills were sent to a conference committee.

Swift adoption by the House of the far-reaching changes to the ADA once again had caught the Executive Branch by surprise. Only weeks earlier HEW had transmitted to the White House and Congress its statutorily required response to the Commission study, ${ }^{155}$ which clearly,

151. Oversight on the Age Discrimination Act of 1975 and Extension of the Older Americans Act of 1965: Hearings Before the Subcomm. on Select Education of the House Comm. on Educalion and Labor, 95th Cong., 2d Sess. (1978) [hereinafter cited as $197 \mathcal{S}$ Hearings]. The tone of the hearing was set by Chairman Brademas, who introduced the first witness, Dr. Flemming, by stating that the ADA "was enacted in response to evidence of pervasive and unconscionable age discrimination in our society." $I d$. at $I$. In fact, the ADA was enacted with the expectation that such evidence, if it existed, would be adduced by the Commission in its study-an expectation the Commission failed to fulfill. Dr. Flemming presented the Commission report and urged that Congress adopt its recommendations. Additional testimony concerning the $\mathrm{ADA}$ came from several groups representing the elderly and from members of Congress, especially those on the Select Committee on Aging. None of the witnesses presented any additional evidence, all supported the Commission's recommendations in general terms, and the issues raised by the recommendations received no discussion. See, e.g., 1978 Hearings, supra, at 2-25, 670-86 (testimony of Dr. Flemming), 193-225 (testimony of Jack Ossofsky, Executive Director of the National Council on the Aging), $420-37$ (testimony of Robert J. Ahrens, President of the Urban Elderly Coalition), 556-88 (testimony of Rep. Claude Pepper).

152. See H.R. REP. No. 1150, 95th Cong., 2d Sess. 122-24 (1978). The other amendments in the bill, also recommended by the Commission, included creation of a private cause of action to enforce the $\mathrm{ADA}$, a requirement that HEW give prior approval to all regulations issued by other departments or agencies under the ADA, creation of an alternative administrative remedy to enforce the $\mathrm{ADA}$, and a requirement that federal agencies file annual reports on their implementation of the ADA. Id.

153. 124 CoNG. REc. H3912-35 (daily ed. May 15, 1978).

154. The Senate committee did hold hearings on the Older Americans Act legislation, but the ADA was not mentioned, the intention having been to hold separate hearings on the Commission report. These separate hearings, however, were never held. Interview with Steve Rowling, staff of Sen. Eagleton (Jan. 18, 1979) (notes on file with Yale Law Journal).

155. See Letter from Secretary Califano to Nelson Cruickshank, Counselor to the President on Aging (April 28, 1978) (HEW response to Commission on Civil Rights' Age 
though gently, criticized the Commission's assumptions and methodology and opposed with particular vigor any change in the existing exceptions and exclusions to the ADA.

When the full House approved sweeping amendments to the ADA, however, HEW belatedly swung into action. ${ }^{156}$ It distributed a summary analysis of the House amendments, opposing most of them and pointing out their potential effects on existing federal, state, local, and private programs. ${ }^{157}$ Significantly, this marked the first time since the genesis of the ADA in 1975 that the meaning and policy consequences of either the original statute or the proposed amendments had been clearly addressed. HEW's resistance precipitated negotiations within the Administration ${ }^{158}$ that led to a letter from Secretary Califano to

Discrimination Study) (on file with Yale Law Journal). Copies of the document also were sent to the chairmen of the House and Senate authorizing committees. HEW did agree that the word "unreasonable" could be deleted from the purpose clause, provided that the reasonableness exceptions were retained, thereby continuing to allow reasonable age distinctions in HEW-supported activities. Id. at 7-10.

156. HEW had been assured by committee staff that only procedural amendments (such as creation of a private remedy) would be proposed, and it learned of the House action only in late May, several weeks after passage of the House bill. Interview with William A. Blakey, HEW Deputy Assistant Secretary for Legislation (Education) (May 1978) (notes on file with Yale Law Journal).

157. See HEW Fact Sheet, supra note 146. This analysis was given on a very limited basis to certain members of Congress, committee staff, White House staff, and the Office of Management and Budget (OMB); OMB circulated it to other Executive Branch departments and agencies, including the Civil Rights Commission.

158. The Civil Rights Commission reaffirmed its support for the House amendments, but suggested that the bill include a provision authorizing HEW to grant temporary waivers, pending congressional review, for state or local laws containing age distinctions. Letter from Arthur S. Flemming to Naomi R. Sweeney, OMB (undated) (on file with Yale Law Journal). The Equal Employment Opportunity Commission (EEOC) also wrote in support of the House amendments, expressing its belief that they would not preclude the use of reasonable age distinctions by program administrators. Letter from William $F$. Ware, EEOC, to Naomi R. Sweeney, OMB (June 26, 1978) (on file with Yale Law Journal).

These defenses of the House amendments were weak: the Commission's, because its new proposal would be administratively unworkable, would authorize far broader exceptions than the ADA permitted, and represented a tacit admission that the House amendments would create great mischief if unchanged; the EEOC's, because it was utterly inconsistent with the clear language and intent of the House amendments. HEW wrote to OMB to highlight the difficulties with both the House amendments and the Commission's pro. posal, citing letters from other departments in support of the HEW analysis. Memorandum from Inez Smith Reid and Henry Aaron, HEW, to Suzanne Woolsey, OMB (Aug. 25, 1978) (on file with Yale Law Journal).

As the September date for convening the House-Senate conference approached, White House staff pressed HEW and the Commission to reach an accommodation. Dr. Flemming then proposed that the temporary waiver approach might be joined with another amendment limiting the ADA's applicability to the elderly; this generated immediate opposition by children's groups. HEW began to soften its opposition to some of the House amendments, while stiffening its resistance to what it regarded as the most pernicious ones: the repeal of the reasonableness exceptions, and the requirements that HEW approve the ADA regulations of other agencies and monitor a burdensome data-gathering and reporting system. On September 8 , with the conference only days away, the White House convened a meeting of HEW, Civil Rights Commission, EEOC, OMB, and other 
the conferees opposing any change in the exceptions or exclusions. ${ }^{159}$ When the conference committee next met, it noted Califano's letter, expressed satisfaction that a compromise had been reached, and quickly adopted the Administration's position. ${ }^{100}$ The President signed the

Executive Branch officials to reach agreement upon an Administration position. That meeting produced agreement that resulted in a September 12 letter from Secretary Califano to the conferees.

159. Letter from Secretary Califano to conferees on Older Americans Act amendments (Sept. 12, 1978) (on file with Yale Law Journal). This letter also addressed other sections of the Older Americans Act amendments, and urged:

that action at this time be limited to four points: authorization of a private right of action ... ; provision of an alternative administrative remedy in the event that any recipient of Federal assistance is found in violation of the Act; striking of the word "unreasonable" in Section 302 of the existing Act, only so long as the exemptions [sic] currently in the law remain in place; and amendment to change the effective date of Section 303 from January 1, 1979, to July 1, 1979, in order to permit the necessary publication of proposed regulations and the receipt and evaluation of public comment. Id. at 1-2.

160. See H.R. REP. No. 1618, 95th Cong., 2d Sess. 47-48, 87 (1978). When the conference report was issued, it was apparent that a misunderstanding had occurred. One House amendment had required that HEW approve all regulations issued by other agencies under the ADA, that each agency submit to HEW an annual report containing specific age data on program participants "sufficient to permit analysis of how well the department or agency" was implementing the ADA, and that HEW evaluate "the performance of each department or agency" in complying with the ADA. HEW had continuously and strenuously opposed these provisions. Although the conferees had agreed to delete these provisions, the conference report inexplicably contained both provisions unchanged.

HEW officials had several concerns. Prior approval of other agencies' regulations would generate substantial interdepartmental friction, would create an enormous workload for HEW staff, and could set an unfortunate precedent. The data-gathering and reporting requirements were even more troubling. According to rough estimates compiled by HEW staff, the potential cost of the data-collection effort could be staggering-hundreds of millions of dollars or more, if the requirement were fully implemented-because many of the hundreds of federal grant programs collect little or no participant data. Moreover, the data, once compiled, would prove little about the presence or absence of age discrimination in a particular program. Even if these other difficulties were surmounted, HEW clearly would not be competent to evaluate the implementation efforts of other agencies and would be placed in an awkward political position by such a requirement.

HEW sought to correct the apparent misunderstanding, which it acknowledged probably resulted from a combination of ambiguity in the September 12 letter to conferees, and the chaotic environment of an end-of-session conference on such major legislation. It raised the matter with Representative Brademas, Senator Eagleton, and their staffs, but too late; congressional rules preclude any nontechnical amendment to a conference report. Unwilling to recommend a veto of the massive, delicately negotiated legislation for what would, in the larger scheme of things, surely seem trivial, HEW requested that Brademas and Eagleton make floor statements committing themselves to seek repeal of these provisions prior to the new July 1, 1979 effective date of the ADA regulations. While each made a floor statement setting forth the Administration's objections to the provisions, neither made any commitment to seek legislative change. 124 CoNG. Rec. H11,446 (daily ed. Oct. 4, 1978) (remarks of Rep. Brademas), id. at S17,679 (daily ed. Oct. 7, 1978) (remarks of Sen. Eagleton). To make matters worse, Congress adopted a concurrent resolution adding to the $1978 \mathrm{ADA}$ amendments a provision creating a new administrative remedy; the provision had been agreed to in conference, see id. at H11,446 (daily ed. Oct. 4,1978 ), but was inadvertently omitted from the conference report. That resolution failed to address, however, the provisions to which HEW objected so strenuously, probably because any such amendment would not have been merely technical. HEW's effort to devise relatively inexpensive data requirements appears at 44 Fed. Reg. 33,784 (1979). 
Older Americans Act legislation, including the 1978 amendments to the ADA, on October 18.161 The exceptions and exclusions remained unchanged. In June 1979, after holding public hearings and receiving written public comments, HEW issued the general, governmentwide regulations under the ADA to which each federal department and agency must conform its own additional regulations. ${ }^{162}$

\section{Interpreting the ADA: Reading Shadows on Walls}

While little else may be certain about the ADA, it is clear that it will spawn a great deal of litigation. Several aspects of the ADA invite efforts to test its limits and meaning: the programmatic breadth of its coverage, which includes virtually all federally assisted activities; the sweeping nature of its prohibitory language; its ambiguous exceptions and exclusions; its unusually sparse legislative history; the manner in which HEW interpreted the reasonableness exceptions in its governmentwide regulations; ${ }^{163}$ and the continuing (indeed, after the Commission's report, growing) uncertainty concerning the nature, meaning, and extent of age discrimination. The creation in the 1978 amendments of a statutory scheme for private enforcement, together with provision for award of reasonable attorneys' fees to prevailing plaintiffs, will surely spur court challenges. ${ }^{164}$

The ADA regulations issued by HEW leave open most of the difficult legal and policy choices under the statute. In attempting to determine the meaning of the ADA's ambiguous provisions, the agencies and courts will confront two major sets of issues: the scope

161. 14 Weekly Comp. of Pres. Doc. 1792-94 (Oct. 18, 1978). In addition to the amendments that the Administration had agreed to in the September 12 letter, the law included a requirement of prior approval of regulations by $H E W$ and imposed datagathering and reporting requirements. Amendments to the Older Americans Act of 1965, Pub. L. No. 95-478, $\$ 401,92$ Stat. 1555 (1978) (codified at 42 U.S.C.A. $\$ 6104$ (West 1979)).

162. 44 Fed. Reg. 33,768 (1979) (to be codified at 45 C.F.R. $\$ 90$ ). Each agency must publish its proposed regulations no later than 90 days after the publication date of the final HEW regulations, and must submit its final regulations for HEW approval no later than 120 days after publication of the proposed agency regulations. Thus, the ADA will not be fully implemented until some time in 1980, at the earliest.

163. See pp. 71-72 infra.

164. Numerous organizations advocate and litigate the rights and interests of the elderly, including the National Council of Senior Citizens, the National Council on Aging, and the American Association of Retired Persons. See R. ButLer, supra note 58, at 334-43; H. PRATT, supra note 63, at 86-103. These organizations, as well as the child-advocate organizations, will doubtless find this remedy to be an effective advocacy tool. A parallel private remedy against entities receiving revenue-sharing funds also exists. See note 166 infra. The governmentwide regulations under the $\mathrm{ADA}$ establish a system to mediate complaints. 44 Fed. Reg. 33,768, 33,775 (1979) (to be codified at 45 C.F.R. $\$ 90$ ). The brief time periods provided, however, may prevent mediation from diverting a large number of complaints away from the courts. 
of the activities to which the ADA applies, and the scope of the reasonableness exceptions from its prohibition. Consistent with the conceptualization of age as a classificatory criterion developed in Part $I$, I shall argue that in the absence of clear congressional guidance, agencies and courts should approach these interpretive questions in a permissive spirit, rejecting only those uses of age for which the consequences on the whole appear to be manifestly undesirable, and rejecting only those non-age factors that are clearly arbitrary or are used with an intent to discriminate invidiously.

\section{A. The Coverage of the $A D A$}

The ADA applies to all "programs or activities receiving Federal financial assistance, ${ }^{105}$ including programs or activities receiving funds under the State and Local Fiscal Assistance Act of 1972."168 Two

165. 42 U.S.C. $\$ 6101$ (1976). The phrase "program or activities receiving federal financial assistance," which defines the scope of coverage of the ADA at the broadest level, derives from similar language in Title VI and $\$ 504$. It also appears in Title IX, but there is limited to "education program or activity." 20 U.S.C. $\$ 1684$ (1976). Section 504, unlike Titles VI and IX, contains no exclusion for contracts of insurance or guaranty. Compare 29 U.S.C. $\$ 794$ (1976) (codifying $\S 504$ ) with 42 U.S.C. $\$ 2000 \mathrm{~d}-4$ (1976) (Title VI) and 20 U.S.C. $\$ 1685$ (1976) (Title IX).

Although its precise limits have not been established, the phrase is clearly quite broad. See, e.g., Bob Jones Univ. v. Johnson, 396 F. Supp. 597, 604 (D.S.C. 1974), aff'd per curiam, 529 F.2d 514 (4th Cir. 1975) (review of Title VI history warrants expansive reading of provisions). But see Board of Pub. Instruction of Taylor County, Fla. v. Finch, 414 F.2d 1068, 1078 (5th Cir. 1969) (adopting limited reading of authority to terminate certain funds under Title VI). Federal agencies have construed the phrase broadly in their regulations. See, e.g., 45 C.F.R. $\$ \S 80.13(\mathrm{f})$, (g) (1978) (HEW Title VI regulation); id. $\S 84.3(\mathrm{~h})$ (HEW \$ 504 regulation).

Because of the high utilization of health care services by the elderly, an important coverage issue under the $\mathrm{ADA}$ is its applicability to the hundreds of thousands of providers under the Medicare and Medicaid programs. By analogy to Title VI and $\S 504$, the ADA appears to be applicable to providers under Medicaid and under the basic Medicare program ("Part A"); the situation with respect to Part B of the Medicare program is less clear. See 45 C.F.R. $\$ 84$, app. A, subpt. A (construing applicability of HEW regulations to Medicare providers). In the past, Part B of Medicare, which provides for supplementary medical insurance at the option of the beneficiary, generally has not been construed to constitute federal financial assistance under either Title VI or $\$ 504$. $I d$. Though there is no reason to regard Part $\mathrm{B}$ differently under the ADA, the issue has been under active reconsideration by HEW. Interview with Office of General Counsel, HEW (January 25, 1979) (notes on file with Yale Law Journal).

166. 42 U.S.C. $\$ 6101$ (1976). The phrase "including programs or activities receiving funds under the State and Local Fiscal Assistance Act of 1972" refers to programs or activities funded under general revenue sharing. 31 U.S.C. $\$ 1221$ (1976). The general revenue sharing legislation was itself amended in 1976 to provide that the prohibitions of the ADA and $\$ 504$ also would apply to "any program or activity of a State government or unit of local government, which government or unit receives funds made available under" the general revenue sharing law. State and Local Fiscal Assistance Amendments of 1976, Pub. L. No. 94.488, $\S 8,90$ Stat. 2341 (1976) (codified at 31 U.S.C. $\$ 1242(a)(1)$ (1976)). Because of the difficulty of tracing the disposition of revenue-sharing funds after they are received by a locality, however, the 1976 amendment provided an exemption 
exclusions from this comprehensive coverage exist, however; one is for certain employment-related practices, ${ }^{167}$ and the other for programs "established under authority of" certain types of laws. The latter exception has particularly significant legal and policy implications. Section 304(b)(2) of the ADA provides:

The provisions of this title shall not apply to any program or activity established under authority of any law which (A) provides any benefits or assistance to persons based upon the age of such persons; or (B) establishes criteria for participation in age-related terms or describes intended beneficiaries or target groups in such terms. ${ }^{168}$

The scope of this exclusion is important in determining the impact of the ADA because numerous federal, state, and local laws and regulations contain age distinctions, ${ }^{169}$ and because programs or activities qualifying under section 304(b)(2) need not qualify under the reasonableness exceptions. One question of statutory interpretation is particularly crucial: beyond federal statutes, which are clearly included, what categories does the phrase "established under authority of any law" embrace?170 Depending upon how this issue is resolved, the ADA's coverage could range from extremely narrow to quite broad.

from the prohibition only where the state or local government demonstrated by clear and convincing evidence that the allegedly discriminatory program or activity was not in fact funded with general revenue-sharing funds. 31 U.S.C. $\$ 1242(a)(2)(A)(1976)$. This shift in the burden of proof as to use of federal assistance may effectively expand the scope of the ADA's coverage to situations in which a program is not designated as receiving revenue sharing funds, but revenue sharing funds free up nonfederal funds that are then used by the program in a discriminatory manner. See S. REP. No. 1207, 94th Cong., 2d Sess. 27, (1976), reprinted in [1976] U.S. Code Conc. \& Ab. News 5151, 5177 (1976). This prohibition, like that in the ADA itself, was fortified by provision of a private remedy buttressed by awards of reasonable attorneys' fees, 31 U.S.C. $\$ 1244$ (1976), thereby providing an additional remedy for many plaintiffs in age discrinnination cases, albeit one subject to somewhat different procedures. Indeed, the congressional debate concerning the ADA emphasized the existence of other potential remedies for age discrimination under federal law and the intention to retain them unchanged. See, e.g., 121 Conc. REc. 37,735 (1975) (remarks of Sen. Eagleton); id. at 37,748 (remarks of Sen. Cranston).

167. See 42 U.S.C. $\$ 6103(c)(1976)$. The legislative history of this provision suggests a gradual narrowing of the exclusion. See H.R. Res. 3922, $\$ 308$, 94th Cong., Ist Sess., 121 Cong. REc. 9203, 9209 (1975); 121 Cong. Rec. 9212 (1975); Conference Report, supra note 9, at 58; 44 Fed. Reg. 33,776 (1979) (to be codified at 45 C.F.R. $\$ 90$ ); Pub. L. No. 95-256, § 3, 92 Stat. $189(1978)$.

168. 42 U.S.C. $\$ 6103(\mathrm{~b})(2)$ (1976).

169. See pp. 53-54 supra; HEW Fact Sheet, supra note 146 (citing examples).

170. Another question-whether the two "which" clauses in 42 U.S.C. $\$ 6103(\mathrm{~b})(2)$ (1976) modify the phrase "program or activity" or the phrase "any law"-is one of the few questions to which the meager legislative history provides a fairly clear answer: the clauses modify "any law." See Conference RePort, supra note 9, at 58; 121 Cong. Rec. 9209 (1975); Memorandum, supra note 98, at 3. 
The legislative history reveals only one direct reference to section $304(b)(2)$ that even arguably sheds any light on this question, and that reference cannot be regarded as very helpful. ${ }^{171}$ Several other passages, not explicitly directed at section 304(b)(2), could support an argument that "program or activity established under authority of any law" in this context does not include programs or activities established pursuant to regulations, but embraces only those established pursuant to statute. Such support, however, is at best indirect. ${ }^{172}$ The contrary argument-that the phrase extends to programs authorized by regulation validly promulgated pursuant to statute-finds no explicit support in the legislative history, and must instead rest upon one or both of two notions: (1) that "any law" includes any official issuance (such as regulations) having the force of law; ${ }^{173}$ and (2) that "established under authority" has a more expansive reach than "established in" or "established by" any law would have, and would include any action that is ultimately legitimized by statute.

Whether regulations fall within the exclusion or not, a most farreaching question remains: does the phrase "any law" refer only to federal law? The legislative history, while bearing only indirectly on

171. In explaining the addition of clause (B), the Conference Report noted that the House bill limited the exclusion to "programs for which the law provides benefits to persons based on such person's age, such as with Social Security." Conference REPorr, supra note 9, at 58. Social Security is clearly cited, however, merely as one example of such a law; there is no implication that, because the age-based Social Security program is established by statute, "law" is tantamount to "statute."

172. The most persuasive support for this proposition appears in the Conference Report's discussion of the conferees' lack of consensus as to which age-related distinctions are "reasonable." Id. at 56. The report notes "basic differences on the extent to which age may validly be taken into account by program administrators in determining who is eligible to participate in programs, in the absence of statutorily-established criteria regarding age." Id. The last clause could be a reference to $\$ 304(\mathrm{~b})(2)$; see 121 CoNG. REc. 37,299 (1975) (remarks of Rep. Quie) (ADA "does not apply to reasonable and necessary distinctions based upon age, or to distinctions which are made pursuant to a statute or necessary to the achievement of a statutory objective"); $i d$. at 37,735 (1975) (remarks of Sen. Eagleton) (referring to Social Security and to "legislation," but in context of discussing reasonableness exceptions rather than $\S 304(\mathrm{~b})(2)$ ). The HEW memorandum distributed earlier to the conference committee staff appeared to have assumed that the $\$ 304$ (b)(2) exclusion might not embrace regulations but would embrace certain state plans. Memorandum, supra note 98 , at 4 .

173. Cf. 42 U.S.C. $\$ 1983$ (1976) (establishing federal right of action for deprivation of rights "under color of any statute, ordinance, regulation, custom, or usage"). The phrase "under the authority of any law" was recently used elsewhere by Congress in the Food Stamp Act, 7 U.S.C.A. $\$ 2013$ (b) (West 1979), but no reported case has yet construed this clause of the provision. The Department of Agriculture's General Counsel, if confronted with a regulation arguably relevant to this provision, would construe the provision to include such a regulation on the basis of the presumed congressional intent underlying the provision. See Memorandum from Margaret Porter, Office of General Counsel, HEW, to Inez Smith Reid, Deputy General Counsel, HEW (May 16, 1978) (on file with Yale Law Journal). 
this question, suggests that the exclusion extends beyond federal law. ${ }^{174}$ To the extent that state law is embraced within section 304(b)(2), local law should be embraced as well, for the latter is an extension of the former. Because the precise division of legislative powers between state and local jurisdictions varies from state to state, ${ }^{175}$ the contrary viewthat state law is exempted but local law is not-would mean that the same rule might well be exempted in one state and covered in another. So long as a local ordinance possesses the requisite degree of formality to qualify as a "law," it should qualify for the exclusion.

Although these conclusions with respect to state and local law are based upon the most meager intimations in the legislative history, they are nevertheless fortified by certain practical considerations. Regulation of public health, morals, and safety-the exercise of the police power-has traditionally been a state and local function and has employed numerous age distinctions that are seldom controversial.170 It is most unlikely-and certainly the legislative history does not suggest-that Congress, in enacting the ADA, intended to disturb these and many other such provisions of state and local law. Indeed, it is doubtful that Congress intended even to raise any question as to their continuing validity. ${ }^{17 \tau}$ Only by excluding state and local law from coverage by the ADA could such immunity be assured. ${ }^{178}$ The govern-

174. Three pieces of evidence support this conclusion. First, when the conference was deliberating over the ADA in October 1975, HEW officials were told by the conference committee staff that the phrase "any law" was meant not to be limited to federal law, but should include state and local laws as well. See Memorandum, supra note 98, at 4. Second, the House adopted an amendment to the ADA in 1978 that would have transformed $\S 304(b)(2)$ into an exception limited to actions "specifically directed or provided by the terms of a Federal statute" that provides age-conditioned benefits or establishes agerelated criteria for participation. 124 CoNG. REc. H3924, 3934 (daily ed. May 15, 1978). This amendment was deleted in conference, H.R. ReP. No. 1618, 95th Cong., 2d Sess. 87 (1978), reprinted in part in [1978] U.S. Cone ConG. \& AD. News 3429, 3463, which suggests that, by retaining the more general "under authority of any law" foundation, Congress preferred to exclude from coverage more than simply federal statutes. Third, Congress's reference to "the goals of the Federal statute" in the 1978 amendment to $\$ 8305(\mathrm{~b})$ of the ADA could be taken to suggest that the broader phrase "any law" was not intended to be limited to federal statutes. See 42 U.S.C.A. $\$ 6104$ (West 1979).

175. D. Lockard, The Politics of State and Local Government $5 \cdot 6$ (1969 ed.) (noting vast differences in ways states divide political power).

176. Disagreements, when they exist, tend to concern the particular age cut-offs that should be employed, not the legitimacy of some age distinction. See HEW Fact Sheet, supra note 146, at 2.

177. The HEW Fact Sheet, circulated in 1978 to head off a House amendment that greatly narrowed $\$ 304(b)(2)$ and eliminated the reasonableness exceptions, noted that the amendment would call these state and local law provisions into question. Id. The amendment was subsequently deleted in conference. See pp. 57-58 supra.

178. It is not obvious that all state law provisions would qualify for one of the reasonableness exceptions, although many surely would. Nevertheless, the Department of Justice 
mentwide regulations under the ADA have adopted this position..$^{170}$ The practical consequences of a narrower interpretation of section 304(b)(2) would be far-reaching; if adopted, thousands of well-established and noncontroversial state and local laws could possibly be brought within the reach of the ADA's prohibition.

\section{B. The Reasonableness Exceptions}

The ADA contains three exceptions to the prohibition against age discrimination ${ }^{180}$ built, both textually and conceptually, upon a fundamental principle: certain uses of age criteria to distinguish between groups of people, and certain uses of non-age criteria that produce different results for different age groups, are reasonable allocative devices and ought to be sustained. It is important to contrast this principle with that underlying Title VI. Racial distinctions would not be accepted under Title VI even if they were deemed "reasonable"; 181 they must be "necessary" to vindicate a "substantial" governmental interest. ${ }^{182}$ No classification on the basis of race or ethnicity has met this test in thirty-five years except when it has been favorable to certain minorities. ${ }^{183}$

has taken the rather surprising position that the "authority of any law" provision should embrace no state statutes. Memorandum from John M. Harmon, Assistant Attorney General, Office of Legal Counsel, Dep't of Justice, to HEW Secretary Joseph Califano at 6 (Feb. 8, 1979) (on file with Yale Law Journal). The Department favored permitting federal statutes and regulations to be excluded from the scope of the ADA, but could sce no basis for such treatment of state statutes and local ordinances. Id. at 6-7.

179. 44 Fed. Reg. 33,776 (1979) (to be codified at 45 C.F.R. $\$ 90.3(\mathrm{~b})(\mathrm{I})$ ).

180. H.R.1255, reprinted in 124 CoNG. Rec. 3912-35 (daily ed. May 15, 1978). Each exception was repealed in the House amendments of 1978 , only to be restored in conference; thus, they remain as originally enacted.

181. See Regents of the Univ. of Cal. v. Bakke, 438 U.S. 265, 291 (1978) (Powell, J., announcing judgment of the Court) ("Racial and ethnic distinctions of any sort are inherently suspect and thus call for the most exacting judicial examination.")

182. Id. at 305 .

183. The last cases to meet this test were the World War II Japanese internment cases, Hirabayashi v. United States, 320 U.S. 81 (1943) (adoption of wartime measure to uphold public safety not unconstitutional even though based on racial distinctions irrelevant in most circumstances), and Korematsu v. United States, 323 U.S. 214 (1944) (upholding order excluding civilians of Japanese descent from certain West Coast areas). Some cases, however, appear to countenance nonpreferential uses of race under very limited circumstances not involving differential benefits. See, e.g., Lee v. Washington, 390 U.S. 333 (1968) (authorizing racial segregation of prisons under limited circumstances, such as racial tension, when required for prison security and discipline); Hamm v. Virginia State Bd. of Elections, 230 F. Supp. 156, 158 (E.D. Va.), aff'd per curiam sub nom. Tancil v. Woolls, 379 U.S. 19 (1964) (upholding statute requiring divorce decrees to denote race of parties). Title VII of the Civil Rights Act of 1964, 42 U.S.C. $\$ 2000$ e (1976), which contains a reasonableness exception similar to one of those in the ADA, makes that exception inapplicable to discrimination on the basis of race. See id. $\$ 2000 \mathrm{e}$ 2(e) (exempting only distinctions based on religion, sex, or national origin). Sex has not 
Courts have recognized that the use of: age to differentiate between groups of people often will be "reasonable" and that the "reasonableness" of such classifications ordinarily will suffice to sustain them against legal challenge under the equal protection clause. ${ }^{184}$ In the leading case of Massachusetts Board of Retirement v. Murgia, ${ }^{185}$ the Supreme Court upheld under the relaxed, rational-basis standard a statute mandating that uniformed state police retire at age fifty. ${ }^{186}$ The Court distinguished age classifications from other classifications that are deemed "suspect" and therefore require strict judicial scrutiny. ${ }^{187}$ The aged, the Court stated, "unlike, say, those who have been discriminated against on the basis of race or national origin, have not experienced a 'history of purposeful unequal treatment' or been subjected to unique disabilities on the basis of stereotyped characteristics not truly indicative of their abilities."188 Furthermore, "even old age does not define a 'discrete and insular' group ... in need of 'extraordinary protection from the majoritarian political process.' Instead, it marks a stage that each of us will reach if we live out our normal span."189

While the Court's cursory analysis of these matters was not wholly satisfactory, ${ }^{190}$ its conclusion-that age discrimination involves different considerations than other prohibited forms of discrimination-seems amply justified. ${ }^{191}$ Many of these considerations already have been

yet been characterized by a majority of the Court as a "suspect" classification. See Regents of the Univ. of Cal. v. Bakke, 438 U.S. 265, 303 (1978) (Powell, J., announcing judgment of the Court) ("the Court has never viewed such [sex-based] classification as inherently suspect or as comparable to racial or ethnic classifications for the purpose of equal protection analysis"); Frontiero v. Richardson, 411 U.S. 677 (1973) (only four of nine Justices finding sex-based classification "suspect"). Nevertheless, Title IX does not generally permit federally assisted education programs to justify differential treatment of the sexes as reasonable. See note 18 supra.

184. U.S. Const. amend. XIV, $\S 1$. If the right in question is "fundamental", however, the age classification will be subjected to strict scrutiny. See Massachusetts Bd. of Retirement v. Murgia, 427 U.S. 307, 312 n.3 (1976) (listing such fundamental rights).

185. 427 U.S. 307,312 (1976). The case was brought under the equal protection clause of the Fourteenth Amendment; no claim was made under the ADEA.

186. Id. at 310 n.2.

187. Id.

188. Id

189. Id. at 313-14 (citation omitted).

190. The Court cited no authority to support either of these propositions or to rebut the contrary point of view; neither did it advert to the fact that Congress had enacted the ADEA, at least, on the basis of opposite premises.

191. See Vance v. Bradley, 99 S. Ct. 939 (1979) (upholding under rational basis test mandatory retirement age under Foreign Service retirement system). But compare Mastie v. Great Lakes Steel Corp., 424,F. Supp. 1299, 1306 (E.D. Mich. 1976) (age discrimination "unique from race, sex or national origin discrimination") with Marshall v. Arlene Knit- 
discussed: the advantages of age as a classificatory criterion; ${ }^{102}$ the demonstrated ability of the elderly to protect their interests in the political process; ${ }^{103}$ the reality of a high correlation between people's ages and certain of their needs and abilities; ${ }^{194}$ the widespread programmatic use of age as a proxy for other characteristics that should not or could not be measured directly; ${ }^{195}$ the ubiquitous and inescapable use of non-age factors having differential age-specific impacts; ${ }^{106}$ and the relatively secure political safeguards against arbitrary uses of age and factors other than age. ${ }^{197}$ It is all the more striking, then, that neither the legislative history of the ADA nor the Civil Rights Commission report reflects recognition, much less discussion, of these considerations. ${ }^{198}$

wear, Inc., 454 F. Supp. 715, 728 (E.D.N.Y. 1978) (age discrimination "equally pernicious" as race and sex discrimination).

192. See pp. 33-35 supra.

193. See pp. 41-42 supra; cf. Vance v. Bradley, 90 S. Ct. 939, 943 n.12 (1979) (describing Congress's 1978 amendments to ADEA restricting mandatory retirement as evidence "that the political system is working"). For an advocate's less optimistic view of the political influence of the elderly, see $R$. BuTLER, supra note 58, at 321-50.

Children present a special case; they have received much protection and attention in the political process, but only at the instance of their parents and other adults. This dependence of children and youths upon others to protect their interests complicates the questions of whether, and to what extent, discrimination on the basis of age can be reasonable. As the law increasingly recognizes conflicts of interest between parents and other supervisory adults on the one hand, and children on the other, notions of reasonable age-based distinctions in the treatment of children increasingly will be called into question. See Burt, The Constitution and the Family, 1979 SuP. CT. REv. (forthcoming); Goldstein, Medical Care for the Child at Risk: On State Supervention of Parental Autonomy, 86 YALE L.J. 645 (1977).

194. See p. 36 supra.

195. See pp. 34-35 supra. Such uses of age also are found in numerous voluntary social arrangements, reflecting the belief that separation by age is often appropriate: e.g., age-based sports leagues, YMCA's, scouting organizations, residential communities for the clderly, and parent-teacher associations. Indeed, such separation will often be a prerequisite for equal treatment of different age groups. See note 217 infra. In contrast, differences between racial or ethnic groups with respect to needs or capabilities are not thought to exist as a function of race or ethnicity; differential or separate treatment on the basis of race, especially treatment that is not preferential to a minority, has long been socially and constitutionally stigmatized. See notes 14 \& 43 supra.

196. See pp. 35-37 supra.

197. See pp. 41-42 supra; O'Donnell, Lasser, \& Bailor, The Federal Age Discrimination Statute: Basic Law, Areas of Controversy, and Suggestions for Compliance, 15 WAKE FOREsT L. REv. I (1979) (examining protections afforded workers by age discrimination legislation).

198. Acknowledgment that such differences even might exist rarely surfaced. See CoNFERENCE REPORT, supra note 9, at 56; 121 CoNG. REC. 37,735 (1975) (remarks of Sen. Eagleton); Memorandum, supra note 98, at 1-2; Fact Sheet, supra note 146, at 1-5; and Letter from Weinberger, supra note 91 , at 1-2. Of these, only the HEW memorandum and Fact Sheet (neither of which was an official document) and Senator Eagleton actually discussed these differences. 


\section{The "Normal Operation" Exception}

Section 304(b)(1)(A) of the ADA provides in part:

It shall not be a violation of any provision of this chapter, or of any regulation issued under this chapter, for any person to take any action otherwise prohibited by [this Act] if, in the program or activity involved-(A) such action reasonably takes into account age as a factor necessary to the normal operation ... of such program or activity. ${ }^{199}$

Despite the breadth, ambiguity, and importance of this exception, there is virtually no legislative history bearing upon either its source or its meaning. ${ }^{200}$ We need not guess at its genesis, however, for it closely parallels the language of the "bona fide occupational qualification" (BFOQ) exceptions in the ADEA ${ }^{201}$ and Title VII.202

The BFOQ exception under the ADEA provides the best analogy-

199. 42 U.S.C. $\$ 6103(b)(1)(A)(1976)$.

200. The original bills contained this exception in the form ultimately adopted. See CONFERENCE REPORT, supra note 9, at 52-55. The only mention of the exception in the legislative history came in the conference report, which simply quoted the exceptions, noting that they modify the prohibition of discrimination "by considerations of reasonableness." Id. at 56 .

201. See 29 U.S.C. $\$ 623(f)(1)(1976)$.

202. See 42 U.S.C. $\$ 2000 \mathrm{e}-2$ (e) (1976). The BFOQ exception is not available under Title VII, however, in cases in which the defendant acted on the basis of the employee's race. $I d . \$ 2000 \mathrm{e}-2(\mathrm{a})$. The Supreme Court recently noted that the BFOQ exception in Title VII was intended as "an extremely narrow exception to the general prohibition of" sex discrimination. Dothard v. Rawlinson, 433 U.S. 321, 334 (1977). The ADA exception is textually different from the BFOQ exception. The BFOQ exception provides that such a qualification must be "reasonably necessary to the normal operation" of a particular business. 29 U.S.C. $\S 623(f)(1)$ (1976) (ADEA); 42 U.S.C. $\S 2000 \mathrm{e}-2(\mathrm{e})$ (1976) (Title VII). The ADA provision, however, excepts an action that "reasonably takes into account age as a factor necessary to the normal operation" of a program or activity. ADA $\S 304(\mathrm{~b})(1)(\mathrm{A}), 42$ U.S.C. $\$ 6103(\mathrm{~b})(\mathrm{I})(\mathrm{A})$ (1976). There is an additional difference: the ADEA and Title VII refer to "the normal operation of a particular business," whereas the ADA refers to "the normal operation ... of such program or activity." Presumably, however, this discrepancy merely reflects the different contexts in which the two laws were to operate: the ADEA and Title VII in employment, the ADA in federally assisted programs and activities.

The legislative history does not mention, much less elucidate, this transposition of "reasonably" and "necessary." Although the displacement may appear to be technical and inconsequential, the two formulations do appear to possess somewhat different meanings, implying a narrower ambit for the ADA exception than for the BFOQ exceptions of Title VII and the ADEA. A requirement that a reasonable use of the age factor be necessary to the normal operation of a program arguably entails a more rigorous showing than a requirement that use of a BFOQ of age merely be reasonably necessary to normal operations. See United States v. 564.54 Acres of Land, 576 F.2d 983, 994 n.14 (3d Cir. 1978), rev'd, 99 S. Ct. 1854 (1979) ("reasonably necessary" as framed by courts means not entirely necessary but somewhat necessary); cf. McCulloch v. Maryland, 17 U.S. (4 Wheat.) 316, 413 (1819) (word "necessary" "frequently imports no more than that one thing is convenient, or useful, or essential to another"). 
although, for reasons discussed later, an imperfect one-for use in deriving the meaning of the parallel exception in the ADA. ${ }^{203}$ Only a handful of cases, however, have construed the BFOQ exception in the ADEA and none has reached the Supreme Court. ${ }^{204}$ The Fifth Circuit decision in Usery v. Tamiami Trail Tours, Inc. ${ }^{205}$ elaborated a two-pronged test based upon principles developed in sex discrimination cases to determine whether the BFOQ exception applies. ${ }^{200}$ Under this test, the employer bears the burden of proving that the age requirement is "reasonably necessary to the essence of his business," 207 and that the employer has "reasonable cause, that is, a factual basis, for believing that all or substantially all persons [within the plaintiff's class] would be unable to perform safely and efficiently the duties of the job involved, or [that] it is impossible or impractical to deal with persons [within the plaintiff's class] on an individualized basis." 208

This test highlights the heavy burdens that the employer must sustain in order to qualify for a BFOQ exception. ${ }^{209}$ The employer must demonstrate business necessity, not business convenience; "the essence of the business operation" must be at stake. 210 The employer aiso must demonstrate either that the generalization upon which the BFOQ rests is true or that its validity as applied to specific individuals would be "impossible or impractical" to test. ${ }^{211}$ Nevertheless, most cases in which age has been advanced as a $\mathrm{BFOQ}$ have involved allegations of

203. It bears emphasis here, as well as with respect to the other exceptions, that nowhere does the legislative history of the ADA indicate that the ADEA either served as the model for the ADA or is to provide an analogy for interpreting the exceptions. The sole reference to the ADEA was in connection with the coverage provisions of $\S 304(\mathrm{c})$ of the ADA. 42 U.S.C. $\$ 6103(c)(2)$ (1976).

204. See, e.g., Marshall v. Westinghouse Elec. Corp., 576 F.2d 588, 591 (5th Cir. 1978);

Lindsey v. Southwestern Bell Tel. Co., 546 F.2d 1123, 1124 (5th Cir. 1977).

205. 531 F.2d 224 (5th Cir. 1976).

206. Id. at 234-36 (test based on holdings in Weeks v. Southern Bell Tel. \& Tel. Co., 408 F.2d 228 (5th Cir. 1969), and Diaz v. Pan Am. World Airways, Inc., 442 F.2d 385 (5th Cir.), cert. denied, 404 U.S. 950 (1971)).

207. Usery v. Tamiami Trail Tours, Inc., 531 F.2d 224, 236 (5th Cir. 1976) (emphasis in original).

208. Id. at 236 (emphasis in original).

209. See Note, The Age Discrimination in Employment Act of 1967, 90 HaRv. L. Rev. $380,388-99$ (1976) (discussing burdens involved in Title VII and ADEA cases).

210. Usery v. Tamiami Trail Tours, Inc., 531 F.2d 224, 234 n.24 (5th Cir. 1976) (emphasis in original); see Harriss v. Pan Am. World Airways, Inc., 437 F. Supp. 413, 432 (N.D. Cal. 1977) ("the asserted business interests . . . must be related to the primary purpose or essence of the business operation" and "the policy must be reasonably calculated to further" those interests).

211. This second prong of the test will be difficult to apply. Though determining suitability on an individual basis will rarely be impossible, it will often be expensive. The trade-off between the desirability of individualized employment decisions and the costs to the employer has not been treated as a serious problem by the courts, perhaps because they have been dealing with relatively clear-cut cases. 
safety risks allegedly brought about by employing older workers, ${ }^{212}$ and courts in such cases have been receptive to this defense, stressing the importance of affording the employer "substantial discretion in selecting specific standards which, if they err at all, should err on the side of preservation of life and limb." 213 Where safety considerations have been less compelling, however, courts have been less deferential to employers. ${ }^{214}$

Some important differences in context, however, argue against courts and agencies casually adopting BFOQ principles developed under Title VII and the ADEA when construing the ADA. First, textual disparities between the BFOQ provisions and the normal operation exception may justify different interpretations. ${ }^{215}$

Second, the phrase "normal operation" often will be more difficult to define in the context of federally assisted programs than in the context of businesses covered by the ADEA. Federal programs often have purposes that are vague, ambiguous, conflicting, and changing over time; they also are operated in a political environment in which their "normal operation" is relatively ill-defined. The criteria of safety and efficiency of a business, so conspicuous in the cases interpreting BFOQ under Title VII and ADEA, require different meanings when applied to complex public programs such as public service employment under CETA. ${ }^{216}$ Moreover, the kinds of evidentiary showings needed to

212. E.g., Usery v. Tamiami Trail Tours, Inc., 531 F.2d 224 (5th Cir. 1976) (upholding as $B F O Q$ rule prohibiting initial employment of individuals over 40 years old as intercity bus drivers); Hodgson v. Greyhound Lines, Inc., 499 F.2d 859 (7th Cir. 1974), cert. denied, 419 U.S. 1122 (1975) (upholding as BFOQ rule requiring intercity bus drivers be under 35 ). But see Houghton v. McDonnell Douglas Corp., 553 F.2d 561, 564 (8th Cir.), cert. denied, 434 U.S. 966 (1977) (employer transfer of 53-year-old test pilot to nonflying position on basis of age not upheld as BFOQ because evidence did not support generalization and accurate individual testing was possible).

213. Usery v. Tamiami Trail Tours, Inc., 531 F.2d 224, 238 (5th Cir. 1976).

214. See, e.g., Rodriquez v. Taylor, 428 F. Supp. 1118 (E.D. Pa. 1976), vacated on other grounds, 569 F.2d 1231 (3d Cir. 1977), cert. denied, 436 U.S. 913 (1978) (city's maximum age requirement of 41 for initial employment of security officer not BFOQ where safety factor not important, and inexpensive and accurate tests can be devised to test suitability); Aaron v. Davis, 414 F. Supp. 453, 462 (E.D. Ark. 1976) (mandatory retirement age of 62 for fireman not $B F O Q$ where safety factors less important than in Hodgson v. Greyhound Lines, Inc., 499 F.2d 859 (7th Cir. 1974), cert. denied, 419 U.S. 1122 (1975), and no showing that periodic physical examination could not test suitability).

215. See note 202 supra.

216. Because most cases applying the BFOQ exceptions have involved safety considerations that both parties agree are at the heart of the normal operation of the business in question, the courts have not spoken clearly on the meaning of that phrase, focusing instead on the question of whether the age or sex requirement is reasonably necessary to the vindication of those safety objectives. Nevertheless, "normal operation" seems to be interpreted as "essence" in Title VII cases. See Dothard v. Rawlinson, 433 U.S. 321, 333 (1976) (quoting Diaz v. Pan Am. World Airways, Inc., 442 F.2d 385, 388 (5th Cir. 1971)) 
qualify for the normal operation exception often will be more difficult to make than the showing needed for a BFOQ exception. It is one thing to require employers to adduce data justifying age limitations for bus drivers or aircraft pilots; it is quite another to require data showing, for example, that targeting scarce social services funds on day care for preschoolers (rather than infants, toddlers, or school-age children) or on adoption agencies that place only infants (rather than say, teenagers), is "necessary to the normal operation" of the program in question. The former can be done through conventional testing of physical capabilities for performing a well-defined job; the latter depends not so much upon empirical relationships as upon normative and highly debatable hypotheses concerning the nature of the program, who is responsible for defining the program, the relationship between program operations and complex social phenomena such as child development or family stability, and the share of program benefits that should be regarded as fair and responsive to need with respect to different age groups.

Third, public programs, because they are financed with tax dollars, are and ought to be more concerned than private employers with the equal treatment of large groups of people. This assumption suggests that it often will be necessary to treat different age groups differently or even separately in order to treat them equally. ${ }^{217}$ Moreover, "bright line" rules, such as age requirements, often will be necessary in order to minimize the exercise of official discretion in allocating public benefits or enforcing public prohibitions on the basis of criteria that are difficult to measure or to apply objectively and that are therefore

("discrimination based on sex is valid only when the essence of the business would be undermined by not hiring members of one sex exclusively") (emphasis in original). Similarly, cases under the ADEA seem to adopt the "essence" construction. See Usery v. Tamiami Trail Tours, Inc., 531 F.2d 224, 236 (5th Cir. 1976) (safe transportation "essence" of bus service).

The definition of "normal operation" in the governmentwide regulations under the ADA-"the operation of a program or activity without significant changes that would impair its ability to meet its objectives"-seems somewhat broader than "essence." See 44 Fed. Reg. 33,777 (1979) (to be codified at 45 C.F.R. $\$ 90.13$ ). The Department of Justice favors a far broader construction of the exception, one that would permit age-limited medical school admissions policies on the basis of cost-benefit considerations. Memorandum from John M. Harmon, supra note 178, at 10-11.

217. See Lau v. Nichols, 414 U.S. 563, 566-67 (1974) (Title VI regulations require differential treatment of protected group). Like the handicapped, the elderly often require special housing because of their medical, homemaking, transportation, and other needs. Cf. 45 C.F.R. $\$ 84.4$ (b)(iv) (1978) (prohibiting different or separate aids, benefits, or services to handicapped "unless such action is necessary to provide [them] with aid, benefits, or services that are as effective as those provided to others"); id. $\$ 80.3$ (b) (prohibiting different treatment for recipients under any program receiving federal assistance, with lone exception for affirmative action to overcome effects of prior discrimination). 
subject to the risk of abuse, manipulation, and unjust application. ${ }^{218}$ It would be intolerable, for example, for public officials to determine on an individualized basis which young people were mature enough to vote, view "adult" movies, leave school, consent to sexual intercourse, be subjected to the adult criminal justice system, or operate a motor vehicle; to determine which elderly people should be subjected to the "retirement test" or receive Social Security benefits; or to determine which middle-aged persons should remain eligible for a military draft. In contrast, employers usually are concerned with relatively few characteristics, such as physical strength or possession of certain skills, and these usually can be measured rather easily on an individualized basis without much risk of unfairness. ${ }^{219}$

Finally, the economic incentives confronting employers and those confronting operators of federally assisted programs are very different. Quite apart from whether an invidiously discriminatory purpose exists, an employer often will have a strong economic incentive to terminate older workers first-or refrain from hiring them at all-because the employer believes that they occasion both higher direct costs, arising from higher salaries, fringe benefits, and pension rights, and higher indirect costs, arising from the possibility that older workers will be less productive or adaptable. ${ }^{220}$ In contrast, most programs covered by the ADA have no obvious economic incentives to adopt policies that disadvantage particular age groups, and may have some political incentives not to do so. ${ }^{221}$

Overall, these considerations militate in favor of a broader construction of the normal operation exception to the ADA than of the comparable BFOQ provision of the ADEA. Nevertheless, such a rule

218. See Goldstein, On Being Adult in Secular Law, 105 Dakdalus 69, 72 (1976) (explaining "bright-line" phenomenon for age).

219. Cf. Note, supra note 209 , at 410 ("availability of alternative, affordable tests to determine exactly the point at which degenerative processes do begin may be extremely limited").

220. See Note, The Cost of Growing Old: Business Necessity and the Age Discrimination in Employment Act, 88 YALE L.J. 565, 572-87 (1979). The extent to which an employer may respond to those incentives without violating the ADEA is not altogether clear. $I d$. at 574-87; cf. Trans World Airlines, Inc. v. Hardison, 432 U.S. 63 (1977) (Title VII does not require employer to incur more than de minimus cost to accommodate religious needs of employee).

221. See pp. 41-42 supra (noting political influence of elderly). There are doubtless some programs in which serving certain age groups is more costly. Nutrition services, for example, may be more costly to provide to the homebound elderly, who find it difficult to congregate at meal sites, than to younger, more mobile beneficiaries. Similarly, adolescents tend to require more costly family planning services than adults. Other programs are likely to benefit some age groups less than others. For example, school-age children will tend not to benefit as much from Head Start as preschoolers, and people over 65 will tend not to benefit as much from job training as workers in their twenties. 
of construction will still call into question the validity of many common uses of age, for the reasonableness of an age-based classification is likely to be determined more upon the basis of subjective choices among conflicting goals than upon objective or conclusive evidence.

Consider, for example, the policy of many medical schools of not accepting applicants over a certain age. ${ }^{222}$ This policy apparently reflects a good-faith effort to allocate a very scarce and publicly subsidized resource-medical school education-to those likely to remain in practice longest, thus maximizing the social benefits from the use of that resource. On the other hand, the age of particular medical students has no apparent bearing on the program of medical education, and certainly is not "necessary to [its] normal operation." At bottom, this issue is one of conflicting values: that society should ensure that its scarce resources are allocated efficiently, ${ }^{223}$ and that age should be irrelevant to an individual's professional opportunities. As such, it is not an issue that can be resolved or even significantly narrowed by resorting to statistical correlations between, for example, age and intellectual ability, or to evidence concerning projected duration of medical practice. ${ }^{224}$

In the end, the availability of the exception in such cases will turn upon value choices by bureaucrats and judges. Those choices should be informed, and in some cases concluded, by the resolution of a number of factual questions: What is the nature of the particular program or activity and of its "normal operation"? What are the ethical, cost, administrative, and behavioral considerations that might justify age classifications? Does the program have a procedure for dealing with the unusual case in which applying the age rule would work a substantial injustice?225 Is there any reason to doubt the good faith of those who devise or apply the rule?

In addition to these factual questions, a crucial issue of law will

222. See I AGE Discrimination Study, supra note 112, at 38 (28 of 114 medical schools specify such restrictions).

223. See 121 Cong. REc. 37,735 (1975) (remarks of Sen. Eagleton).

224. For a decision demonstrating the difficulty of drawing legal conclusions from generalized correlations between age and behavioral characteristics, see Marina Point, Ltd. v. Wolfson, No. Al5829 (Cal. App. Dep't Super. Ct. Dec. 2, 1978), rev'd, 48 U.S.L.W. 2263 (Cal. Ct. App. Oct. 16, 1979). In this case, the trial court held that an apartment complex could not exclude adults with children on the grounds that children in general tend to be noisy and cause damage, because it was not possible to correlate age with degree of disruptiveness. The appellate court reversed, holding that no precise correlation was required. 48 U.S.L.W. 2263, 2264 (Cal. Ct. App. Oct. 16, 1979).

225. The preamble to the governmentwide regulations under the ADA notes that "Other things being equal, an age distinction is more likely to qualify under one of the statutory exceptions if it does not automatically bar all those who do not meet the age requirements." 44 Fed. Reg. $33,768,33,773$ (1979) (to be codified at 45 C.F.R. $§ 90$ ). 
often arise under the normal operation exception: can a program qualify for that exception if it employs an age distinction in order to target its scarce resources on persons or groups likely to maximize the social benefits from the program? The governmentwide regulations under the ADA are decidedly unclear on this fundamental question. ${ }^{226}$ To be sure, this is a genuinely difficult issue. For instance, age is the best, and perhaps the only, proxy for likely duration of medical practice, and likely duration of practice is surely a legitimate consideration in allocating scarce slots in medical school classes. Suppose that the age ceiling were 60; could anyone doubt that a school was justified in imposing such a limitation? And can one reject the medical school's policy and at the same time countenance the policy of a job-training program to target its services on younger workers who will be in the job force longest? Nevertheless, this line of reasoning does ignore the value that society places upon individual self-determination and merit. Moreover, such logic could well be extended to exclude the elderly from almost all general social programs on the theory that the benefits they derive will be ephemeral relative to younger persons.

Given these opposing considerations, it is not surprising that reasonable persons differ on this particular question, ${ }^{227}$ and HEW's position on it is less troubling than is the department's tendency to give short shrift to efficiency or cost-effectiveness objectives. Because the status under the ADA of these objectives will arise more frequently in connection with the other reasonableness exceptions, however, it is considered further below.

226. Id. at 33,773-74 (1979) (to be codified at 45 C.F.R. $\$ 90$ ). Although the regulations place their imprimatur on a youth program, $i d$. at 33,773 , they withhold it from a medical school that limits applicants to persons under age 35 , id. at 33,773-74. This apparent inconsistency is justified on the ground that while a youth organization may have as its objective rendition of services to youth, "achieving a high average longevity of practice for its graduates cannot be considered a program objective for a medical school within the meaning of the act." $I d$. at 33,774 . The only reason given for this conclusion is the assertion that the medical school's "basic objectives" are to train competent graduates, and that these objectives are not impaired if the average duration of its graduates' practice is somewhat reduced. $I d$. ("The 'normal operation' exception is not intended to permit a recipient to use broad notions of efficiency or cost-benefit analysis to justify exclusion from a program on the basis of age.")

227. Compare Additional Statement by Vice Chairman Stephen Horn of U.S. Comm'n on Civil Rights, I Age Discrimination Study, supra note 112, at 52-53 (arguing medical schools should be permitted to include age as one of many factors in deciding fitness of applicants) and Memorandum from John Harmon, supra note 178, at 10 (arguing medical school policy on age limits should qualify for normal operation exception) with I AGE Discrimination STUDY, supra note 112, at 39 (majority of U.S. Comm'n on Civil Rights concludes that "except as statutorily prescribed, all present age discrimination policies uncovered in the study [such as medical school admissions policies] are unreasonable") and 44 Fed. Reg. 33,773-74 (1979) (HEW maintains medical school policy does not qualify for exception). 


\section{The "Statutory Objective" Exception}

Without explanation, the conference committee that fashioned the ADA added to the normal operation exception in section 304(b)(1)(A) a clause creating a second exception for any action that "reasonably takes into account age as a factor necessary to ... the achievement of any statutory objective of" a program or activity. ${ }^{228}$ The conference report stated only that the clause was added "to clarify congressional intent," ${ }^{229}$ a rather cryptic and circular reference.

Although the official legislative history ignores the meaning of this clause, the unofficial history does not. HEW informally had urged the conference committee staff to insert this exception in order to mitigate the potential rigor and narrowness of the normal operation exception. ${ }^{230} \mathrm{HEW}$ sought to address a common problem. Many statutes require use of age-related policies yet do not specify which groups should receive particular statutory benefits. In pursuing such statutory objectives, an agency often targets the program resources on particular age groups; that strategy reflects the agency's "judgment as to the best way to accomplish the goal."231 Most compensatory and special education programs, for example, are conducted in the elementary grades in which they are thought to have their greatest impact, ${ }^{232}$ yet nothing in the authorizing legislation so delimits the target population. Because HEW believed that the normal operation exception was too restrictive to legitimize those types of actions-age distinctions are not, strictly speaking, necessary, but result from budgetary constraintsHEW suggested addition of a clause broadening the exceptions. It was adopted by the conference in slightly altered form. ${ }^{233}$

228. 42 U.S.C. $\$ 6103(\mathrm{~b})(\mathrm{I})(\mathrm{A})(1976)$.

229. CONFERENCE REPORT, supra note 9 , at 58 .

230. See Memorandum, supra note 98 , at 3 . The only congressional discussion of this exception, by Representative Quie, is consistent with HEW's understanding of its purpose: to permit the use of age to target program resources on those groups that can benefit most from them, where such targeting will further the objectives of the authorizing legislation. In supporting the conference report, Representative Quie stated:

Thus, in a bill providing grants for the improvement of reading in the elementary grades, but for which a relatively small sum had been appropriated, the decision could be made to concentrate the effort on the first three grades even though this discriminates against older children. The basis of the decision would be that otherwise the objective of the program would be defeated.

121 CoNG. Rec. 37,299 (1975).

231. See Memorandum, supra note 98 , at 3.

232. Id.

233. Conference Report, supra note 9, at 54-55. The conference committee expanded the exception from the phrase used in the HEW memorandum-"the statutory objective"to "any statutory objective." Id. at 55 .

The relationship between the "statutory objective" and "normal operation" exceptions is unclear. The two overlap insofar as many uses of age needed to maintain normal 
This exception has far-reaching implications for the scope of the ADA's prohibition. In the typical situation in which program funds are limited in relation to the resources needed to serve the entire eligible population, ${ }^{234}$ administratively applied age distinctions could be justified any time those uses of age were reasonably thought to be "necessary to ... the achievement of any statutory objective." For example, the tendency of job-training programs to focus their efforts on younger workers because of their longer remaining working life, or the targeting of Community Health Center funds on preventive health programs for children, might be upheld under such a construction as necessary to maximize the benefits from scarce program funds.

One could advance several arguments against this approach. The first is that Congress's failure to write age-specific targeting into the authorizing statute for a particular program should be taken to indicate congressional intent that the use of age classifications not be permitted. ${ }^{235}$ That argument, however, eliminates the role of agencies in interpreting their governing statutes, ${ }^{236}$ ignores the history of this clause and its meaning as described in the HEW memorandum, ${ }^{237}$ and deprives the reasonableness criterion in the statutory objective exception of any independent meaning. ${ }^{238}$

operations are also necessary to achieve some statutory objective. An example might be the limitation of Head Start programs to four- and five-year-olds. Yet the explanation in the HEW memorandum, coupled with Congress's addition of the second clause, suggests that the exceptions are not identical. The statutory objective exception should be understood to refer to uses of age with a relatively direct relationship to a statutory objective; the normal operation exception, to situations in which age is used for management or operational purposes consistent with, but not required by, the authorizing statute. Examples of the latter often involve implementing detail that can be derived from the statutory purpose only through an extended chain of reasoning. The linkage to the statute authorizing the expenditures will be even more attenuated in cases of covered "activities" that technically are not "programs," such as the activities of the Boy Scouts of America as a sub-grantee of a social services agency receiving federal assistance.

Many federally assisted activities are not conducted pursuant to statute and therefore cannot qualify for the statutory objective exception. Thus, a private medical school that receives federal funds and imposes an age distinction must either qualify for the normal operation exception or eliminate its use of age. The relationship between the statutory objective exception and the exclusion for activities "established under authority of any law" is also unclear, and the legislative history is silent on the issue.

234. This condition will exist for nearly every government program except the entitlement programs, such as Medicare, Medicaid, Social Security, and Food Stamps, in which appropriations are required to cover all eligible persons who claim the statutorily defined benefit or service.

235. See, e.g., I Age Discrimindtion Study, supra note 112, at 42.

236. The principle that courts ordinarily will defer to interpretations of statutes by the agency that administers them, at least with respect to provisions that relate to the administration of an ongoing program, is well-established. See, e.g., Griggs v. Duke Power Co., 401 U.S. 424, 433-34 (1971) (citing cases); Usery v. Tamiami Trail Tours, Inc., 531 F.2d 224, 230 (5th Cir. 1976).

237. See p. 73 supra.

238. The implication to be drawn from Congress's failure to target by age may be 
A second and more troubling objection to this expansive view of the exception was noted above: ${ }^{239}$ such a construction could render the ADA's prohibition virtually meaningless if program administrators could employ cost-benefit or cost-effectiveness calculations that would almost always exclude the elderly because of their lower life expectancy. ${ }^{240}$

That objection, however, is unconvincing. The ADA was not enacted solely for the benefit of the elderly but for all age groups; an age distinction that redounds to the detriment of one group (such as the elderly) must also redound to the benefit of others (such as young workers). That different groups are competing in a zero sum game ${ }^{241}$ with respect to limited program benefits is regrettable but inescapable in a world of scarce resources. When Congress wishes to limit or predetermine the outcome of that competition in order to protect one age group or another, it can easily do so. In view of the broad wording of the reasonableness exceptions and the ADA's coverage of all age groups, however, the ADA should be limited to eliminating the element of arbitrariness from this competition. Under such a construction of the exception, a classification would have to "reasonably take into account age as a factor necessary to" the statutory objective; the tests of reasonableness and necessity, individually and taken together, could be demanding. ${ }^{242}$

Finally, the HEW memorandum and the remarks of Congressman Quie ${ }^{243}$ confirm that this exception was designed to clarify that officials remain free to do what reasonably seems necessary in order to achieve the purposes of their governing legislation-including targeting limited resources where they will be most effective. Certainly, no contrary intent appears in the legislative history. To argue that interpreting the exception to legitimize many, and perhaps most, age distinctions would thereby significantly limit the ADA's prohibitory effect is simply to beg the critical questions: How is age discrimination properly to be defined? And given that definition, how broadly should the prohibition sweep? The distinctive characteristics both of age as a

precisely the contrary. When Congress has wished to confine bureaucratic discretion by imposing distributional formulas or fixed set-asides for particular groups, it has managed to make its intention clear. See note 280 infra.

239. See p. 72 supra.

240. See I Age Discrimination Study, supra note 112, at 17.

241. The term refers to a situation in which a gain to A necessarily implies a loss to B. See J. von Neumann \& O. Morgenstern, The Theory of Games and Economic BeHAVIOR 47 (1944).

242. Thus, for example, use of an age ceiling of 65 for a job-training program might be deemed to qualify under the exception, while a ceiling of 35 might not.

243. See note 230 supra. 
classificatory criterion and of the $\mathrm{ADA}$ as a hybrid form of legislation imply a relatively limited definition of age discrimination, a definition that in turn implies an interpretation of the exception under which relatively few existing uses of age are likely to be prohibited.

The centrality of the cost-effectiveness issue to the meaning of the exceptions is nowhere acknowledged in the ADA's official legislative history (except for Quie's remark), and the governmentwide regulations evade the issue as well. The regulations affirm an incontrovertible principle-that a cost-benefit consideration cannot be the sole justification for using an age criterion; to be continued, the criterion must find validation in one of the statutory exceptions. ${ }^{244}$ But the regulations fail to discuss, much less clarify, a far more consequential issue: the circumstances under which cost-benefit or cost-effectiveness considerations may in fact justify, or be relevant to, the availability of one of those exceptions. ${ }^{245}$ Furthermore, the single clarification of the statutory exception that the regulations do make-construing "any statutory objective" to include only a purpose "expressly stated in" a federal, state, or local statute ${ }^{246}$-is almost certainly erroneous. Because relatively few statutes proclaim their purposes per se, this crabbed interpretation would exclude age criteria reasonably necessary to achieve purposes implicit in the statutory scheme as well as purposes explicit or implicit in the legislative history, ${ }^{247}$ thereby significantly narrowing the scope of the exception. The courts should not hesitate to overturn the HEW interpretation. ${ }^{248}$

244. 44 Fed. Reg. 33,774 (1979) (to be codified at 45 C.F.R. $\$ 90$ ).

245. The regulations mention this issue only in connection with the example of medical school admissions under the "normal operation" exception. See note 226 supra.

246. 44 Fed. Reg. 33,773 (1979) (to be codified at 45 C.F.R. $\$ 90$ ).

247. The proposed regulations presented an alternative formulation-“any purpose either expressly stated in the statute or reasonably inferred from its provisions or legislative history"-as HEW's "preferred interpretation". 43 Fed. Reg. 56,431 (1978). HEW offered no explanation for its change of heart in the final regulations except that "legislative history is a broad concept." 44 Fed. Reg. 33,773 (1979) (to be codified at 45 C.F.R. $\S 90$ ).

248. Reasons for this conclusion include the following: the broader reading of the exception given by HEW in its memorandum to the conference committee and the committee's apparent acceptance of that reading (indeed, the Conference further broadened the exception by changing it to "any statutory objective"), see note 233 supra; the absurdity of not effectuating an objective that is clearly implicit in a statute's provisions or explicit in its legislative history; HEW's unexplained reversal of its earlier preference for a broader interpretation; and the traditional judicial duty to look beyond a statute's express provisions in construing its purposes so as to avoid unjust or foolish results. The principle that courts will defer to agency interpretations of statutes that they administer, see note 236 supra, is a qualified one. See Southeastern Community College v. Davis, 99 S. Ct. 2361, 2369 (1979) (deference is constrained by obligation to honor clear meaning of statute as revealed by language, purpose, and history). The principle does not apply to interpretations of phrases that are neither technical nor are 


\section{The "Reasonable Factors Other Than Age" Exception}

The third ADA exception is concerned not with uses of age distinctions but rather with the use of certain non-age factors. Thus, section $304(\mathrm{~b})(\mathrm{I})(\mathrm{B})$ provides an exception for action otherwise prohibited by the ADA "if, in the program of activity involved, ... the differentiation made by such action is based upon reasonable factors other than age." 249 The legislative history of the $\mathrm{ADA}$ is utterly silent concerning this exception. ${ }^{250}$ Again, however, its source is evident; like the normal operation exception, its formulation is essentially identical to a statutory exception in the ADEA..$^{251}$

The Supreme Court recently reaffirmed that so long as no discriminatory intent lurks behind the use of a facially neutral factor that disadvantages particular groups, that use is constitutionally valid. ${ }^{252}$ The ADA's reasonable factors other than age exception, like that in the ADEA, apparently is designed to extend that principle to the statutory realm. ${ }^{253}$ But which of the many factors other than age are to be considered reasonable?

The Department of Labor has issued interpretations of the ADEA exception identifying a number of factors other than age that may

illuminated by the agency's expertise. Federal Maritime Bd. v. Isbrandsten Co., 356 U.S. 481,498 (1958) (courts retain final authority to interpret statutes); K. DAvis, TrEATISE ON AdMInistrative LAw $\$ 30.09$ (1958) (courts interpret statutes except when technical and nonlegal). Few concepts are more appropriate for judicial construction than that of "statutory objective".

249. 42 U.S.C. $\$ 6103(b)(1)(1976)$.

250. The provision was in the earliest versions of the bill and remained unchanged. The HEW memorandum of Oct. 25, 1975, contains only a brief discussion of the exception. See Memorandum, supra note 98, at 5-6.

251. See 29 U.S.C. $\$ 623(\mathrm{f})(1)(1976)$. A related exception is contained in the Equal Pay Act, 29 U.S.C. $\S 206(d)(1)(1976)$, which prohibits sex discrimination in wage levels, "except where such payment is made pursuant to ... (iv) a differential based on any factor other than sex." See Corning Glass Works v. Brennan, 417 U.S. 188, 205 (1974) (exception unavailable for differential that, although not based on sex, reflected market reality that women would work at same job for lower pay).

252. Personnel Adm'x of Mass. v. Feeney, 99 S. Ct. 2282, 2291, 2296 (1979) (upholding veteran's preference statute benefiting overwhelmingly male class); see Washington $v$. Davis, 426 U.S. 229, 242 (1976) (evaluation of job applicants through written test that had disproportionate adverse effect upon black applicants does not, without more, violate equal protection clause).

253. Even facially neutral factors may violate a statute designed to limit the use of such factors in the absence of adequate justification. See Washington v. Davis, 426 U.S. 229, 246.48 (1976) (Title VII calls for more probing judicial review of and less deference to seemingly reasonable acts of administrators and executives); Griggs v. Duke Power Co., 401 U.S. 424, 433-36 (1971) (Title VII does not preclude testing or measuring procedures, but does proscribe giving them controlling force unless demonstrably reasonable measure of job performance). Regulations issued under Title IX essentially adopt the Title VII test. See 45 C.F.R. $\$ 86.21$ (b)(2) (1978) (requiring validation by defendant of facially neutral admissions criteria that have "disproportionately adverse effect on persons on the basis of sex"). 
qualify as reasonable so long as they are job-related and are applied on an individualized basis rather than on the basis of any "general or class concept." ${ }^{254}$ However, some court decisions construing the exception have contradicted the department's interpretations, ${ }^{255}$ holding that the ADEA's exception permits employers under certain circumstances to take into account in hiring and discharge decisions direct cost considerations such as salary and benefit levels that militate disproportionately against older workers. ${ }^{256}$ In view of the strong correlation that often exists between the age of a worker and a higher direct cost relative to younger workers, such holdings are potentially significant. $^{257}$

Because some services covered by the ADA are certainly more costly to provide to some age groups than to other groups, ${ }^{258}$ such holdings,

254. See 29 C.F.R. $\$ \S 860.103-104$ (1978). Examples of such factors include physical fitness, productivity, educational level, performance on validated employee tests, and antinepotism rules.

255. See Note, supra note 220 , at 572 n.34 (citing cases). Compare Marshall v. Westinghouse Elec. Corp., 576 F.2d 588, 590-92 (5th Cir. 1978) (prima facie showing under ADEA shifts burden of producing evidence to employer, but employee retains burden of persuasion that age was determining factor) and Laugesen v. Anaconda Co., 510 F.2d 307, 313 (6th Cir. 1975) (same) with Moses v. Falstaff Brewing Corp., 550 F.2d 1113, 1114 (8th Cir. 1977) (establishment of prima facie case shifts burden to employer) and Marshall v. Arlene Knitwear, Inc., 454 F. Supp. 715, 728 (E.D.N.Y. 1978) (burden of persuasion shifts after prima facie showing under ADEA, as under Title VII) and 44 Fed. Reg. 33,783 (1979) (to be codified at 45 C.F.R. $\$ 90.16$ ) (governmentwide regulations under ADA shift burden of proof to defendant). In Marshall v. Westinghouse Elec. Corp., the Court reasoned that the "reasonable factors other than age" exception and the BFOQ exception are different, both because the $B F O Q$ is an affirmative defense and because "establishment of a $B F O Q$ necessarily has an effect beyond the case being litigated since it permits an employer to deal with an entire class of persons on an age-related basis in derogation of the statute." 576 F.2d at 591 n.3.

Marshall also recognized a distinction between the concepts of discrimination under Title VI and under the ADEA, such that certain actions that have an adverse impact on the elderly do not raise the same inference of invidious discrimination as would the same actions directed at a racial minority. $I d$. at $591-92$.

256. Compare Mastie v. Great Lakes Steel Corp., 424 F. Supp. 1299, 1318 (E.D. Mich. 1976) (ADEA does not require employees to retain older workers at economic loss) and Donnelly v. Exxon Research \& Eng'r Co., 12 Fair Empl. Prac. Cas. 417, 422 (D.N.D. 1974), aff'd mem., 521 F.2d 1398 (3d Cir. 1975) (same) with 29 C.F.R. $\$ 860.103$ (h) (1978) (prohibiting age-based classifications of workers as group for purpose of comparing costs) and Marshall v. Arlene Knitwear, Inc., 454 F. Supp. 715. 728 (E.D.N.Y. 1978) (sound business judgment cannot include age as important factor in discharging employees).

In Mastie, the Court found that the regulations, 29 C.F.R. $\$ 860.103(\mathrm{~h})$ (1978), permitted the employer to consider cost factors "where such consideration is predicated upon an individual as opposed to a general assessment that the older worker's cost of employment is greater than for other workers." 424 F. Supp. at 316-19. See O'Donnell, Lasser \& Bailor, supra note 197, at 22 \& nn.133-34 (discussing Mastie). Indeed, the Department of Labor itself appears to be inconsistent on this issue. $I d$. at n.134 (regulations, 29 C.F.R. $\S 860$ (1978), do not contain statement explicitly prohibiting employer from considering actual cost of employing individual).

257. See Note, supra note 220 , at 573 n.36, 575-76.

258. See note 221 supra (citing examples). 
if adopted under the ADA exception, could narrow the scope of the ADA's prohibition. ${ }^{259}$ The use of differential cost factors, however, is only one manifestation of a much broader phenomenon that must shape the interpretation of this exception under the ADA: in the course of conducting federally assisted programs, administrators routinely and inescapably use myriad factors other than age, virtually all of which have differential age-specific impacts, often to a marked degree. A liberal construction of this exception ${ }^{260}$ would not imply that such factors could never be deemed unreasonable; thus the use of a facially neutral factor with an intent to discriminate on the basis of age should not qualify for the exception. ${ }^{261}$ Rather, such a construction would simply reflect the fact that differential age-specific impacts are ubiquitous and inevitable in the real world, and that a more restrictive reading of the exception, as the Supreme Court admonished in an analogous context, "would raise serious questions about, and perhaps invalidate, a whole range of tax, welfare, public service, regulatory, and licensing statutes ..."262 Certainly, neither the language nor the legislative history of the ADA suggests that Congress intended such an extreme result. ${ }^{263}$

Notwithstanding these considerations, the governmentwide regulations under the ADA construe the exception far more narrowly, requiring that a non-age factor, in order to be sustained, must bear a

259. One may well argue, of course, that regardless of the manner in which the ADEA counterpart is interpreted, the ADA exception should not be construed to embrace such cost considerations because a taxpayer bears a very different relationship to the government with respect to tax-supported services than an employee bears to his employer with respect to a particular job. In this view, the differential cost of serving different eligible citizens is not an appropriate criterion for a transaction perceived as more properly based upon moral than upon economic considerations. Similar questions will arise under the other ADA exceptions.

260. See pp. 35-37 supra.

261. While the problem of inferring intent to discriminate is a complex one, see Fiss, supra note 35 , at $290-310$, a close analogy is available in the opportunity of employees in Title VII or ADEA cases to show that, although the employer adopted a nondiscriminatory policy, it was in fact a pretext or was discriminatorily applied. See McDonnell Douglas Corp. v. Green, 411 U.S. 792, 802-05 (1973) (worker must be afforded fair opportunity to prove employer's stated reason was pretext for racially discriminatory decision); Note, supra note 220 , at $\mathbf{5 7 8 - 8 1}$. In the ADA context, a finding of pretext should render unavailable the "reasonable factors other than age" exception.

262. Washington v. Davis, 426 U.S. 229, 248 (1976). For this reason, the Department of Justice has construed the exception to permit the use of cost-benefit considerations resulting in age-specific disproportionate impacts. Memorandum from John Harmon, supra note 178, at 12-13.

263. See p. 77 supra. Congress could, if it chose, invalidate the use of factors that caused such impacts; in Title VII and the ADEA, for example, it has done so with respect to certain employment practices not justified by business necessity. See Griggs v. Duke Power Co., 401 U.S. 424, 431 (1971) (prohibiting employment practice with exclusionary effect if unrelated to job performance). 
"direct and substantial relationship" to the normal operation of a program or activity or to the achievement of a statutory objective. ${ }^{264}$ This standard, stricter than the rational relationship standard that HEW originally preferred, is one under which, HEW has acknowledged, "many 'factors other than age' having a differential impact on persons of particular ages might not be permitted to continue." 200 This interpretation is remarkable not only because it calls into question numerous classificatory factors employed rationally and in good faith but also because it is contrary to the clear statutory language. ${ }^{206}$

IV. The Process, Substance, and Form of Age Discrimination Policy

To examine the gestation of age discrimination policy under the ADA is to glimpse the shadows cast by the elusive interaction of problem definition, institutional and political behavior, and legal forms. The spectacle is not a heartening one. The ADA, I have suggested, was conceived with two important genetic defects. First, there was a conceptual failure to define appropriately the nature and extent of the social problem to which the ADA was a response. That problem might have been characterized in a number of ways-for example, as one of invidious bias against certain age groups on the part of decisionmakers; of innocently held but persistent age-related stereotypes; of an inequitable distribution of resources generally among age groups; or of some more limited distributional inequity in particular programs. As we have seen, however, Congress and HEW neglected to provide even a clue as to the nature of the evil in question. Second, there was a failure on the part of policymaking and policy-informing institutions to discharge their most elementary responsibilities.

These two failures were, of course, interrelated and mutually reinforcing. The definition of a policy problem is not merely an intellectual activity, it is also part of a political process characterized by conflict, cooperation, consensus-building and, as the ADA demonstrates, more than a little confusion. Like a river fed by tributaries and controlled by dams, a social policy results from the confluence of many forces-political, social, intellectual, bureaucratic-mediated through formal institutions: Congress, the Executive Branch, and the courts.

Democratic theory and practice endow these institutions with dis-

264. See 44 Fed. Reg. 33,777 (1979) (to be codified at 45 C.F.R. $\$ 90.15$ ).

265. 43 Fed. Reg. 56,433 (1978).

266. The statute provides an exception for "reasonable factors other than age." 42 U.S.C. $\$ 6103(b)(1)(B)(1976)$ (emphasis supplied). 
tinctive roles based upon both the constitutional sources of their power and the distinctive competencies that are imputed to them. ${ }^{267}$ In this view, Congress makes fundamental political choices not only because it is most directly accountable to the electorate, the ultimate source of legitimacy, but also because it possesses significant institutional capacities for informing choice and effecting compromise.288 Executive agencies, although they share many of Congress's capacities to formulate policy, respond to a different array of political influences and constituencies than does the Congress. ${ }^{209}$ To this difference is added others: the more bureaucratic character of the executive establishment; ${ }^{270}$ its greater familiarity with the operational details of programs; the relatively low visibility of its activities; and its responsibilities for translating generalized legislative policies into specific governmental activities, including the actual delivery of services and benefits.

These overlapping competencies and highly disparate political and program perspectives define the pattern of conflict and cooperation between Congress and the Executive Branch in the development of social policy. That pattern is constantly evolving and reflects the exigencies of individual circumstances, political factors, the influence of particular personalities, and the specialized nature of the policy issues in question.

267. See The Federalist No. 47 (J. Madison).

268. Thus, Congress can develop policy without the necessity for a statutory or litigational pretext. See Johannes, Congress and the Initiation of Legislation, 20 PuB. Pol'y 281 (1972); Moe \& Teel, Congress as Policymaker, 85 Political ScI. Q. 443 (1970). It possesses highly developed, specialized organs for gathering, processing, and evaluating information. See J. Harris, Congressional Control of Administration 79-90, 249-98 (1964) (information secured through investigations, appropriations, authorizations). Its mode of deliberation and decisionmaking facilitates the weighing of competing values; the consideration of alternatives, see J. HAvemanN, Congress AND THE BUdget 200-08 (1978); the registering of intensity of preferences, see J. Buchanan \& G. Tullock, The Calculus of Consent 119.42 (1962); and the reconsideration of decisions previously made. It can monitor and influence the implementation of its decisions. See C. HyNEMAN, Bureaucracy in a Democracy (1950); M. Ogul, Congress Oversees the Bureaucracy (1976); MacMiahon, Congressional Oversight of Administration, 58 Polmrical ScI. Q. 161190, 380-414 (1943). Finally, its responsibility for both raising public revenues and for appropriating public expenditures enjoins a sensitivity to the costs, as well as the benefits, of public policies. See R. Fenno, The Power of THE PURse (1966) (study of appropriations in Congrcss); A. Schick, The First Years of the Congressional Budget Process (1976) (examining impact of budget process on policymaking). Indeed, this sensitivity is often so great that Congress contrives in a variety of ways to conceal the costs from the public.

269. See Maass, System Design and the Political Process, in DesIGN of WATER Resource Systems 577-84 (A. Maass, M. Hufschmidt, R. Dorfman, H. Thomas, S. Marglin, \& G. Fair ed. 1962) (Congress and executive compared).

270. But see H. Fox \& S. Hammond, Congressional Staffs 12-25 (1977) (discussion of growth of congressional bureaucracy); Malbin, Congressional Staffs: Who's in Charge Here? 47 Pub. INTERest 16 (1977) (same). 
Yet this matrix of institutional relationships, flexible and commodious as it is, does not adequately describe the process by which the $\mathrm{ADA}$ actually developed. In fact, Congress performed few of the conventional policymaking functions for which it is thought to be admirably designed: it failed to specify the problem; it gathered little information; it failed to articulate and weigh competing values or reduce them to operational terms; it considered no alternatives; and it declined to make hard choices. Having neglected to define the problem, Congress designed a legislative solution that, by reason of its singular indeterminacy, seemed consistent with any number of possible problem definitions. It adopted a sweeping nondiscrimination provision, then riddled it with exceptions and exclusions. These exceptions and exclusions appeared to be designed to afford broad scope for precisely the kinds of allocative criteria-age classifications-that the nondiscrimination provision flatly condemned.

Although the legislative history does not indicate that Congress was even aware of the tensions and contradictions between these two approaches or of the implications of combining them, one may hazard a guess as to its motivation in proceeding as it did. The analogies to previous civil rights legislation evoked symbolic and rhetorical associations that few legislators were inclined to resist. To have done so would have required them to articulate some unpopular truths: that apart from the employment area where the ADEA already existed, the elderly in general have less need of special legal protection than do racial minorities; that most of what the Civil Rights Commission was later to characterize as age discrimination appeared instead to represent nothing more sinister than a series of difficult, but goodfaith, judgments about how scarce resources could best be stretched in pursuit of social objectives; ${ }^{271}$ that such judgments in many, perhaps most, cases could best be made by resort to age criteria; that without increases in resources, gains to the elderly would simply be at the expense of other age groups; and that, accordingly, the evil of age discrimination required a far more limited and refined legislative response than did that of race discrimination..$^{272}$ With the notable exception of Senator Eagleton, however, no legislator was prepared

271. For example, the hearings and public comments that preceded the promulgation of governmentwide regulations under the ADA unearthed few examples of de jure age discrimination that were not, at least on their face, reasonable. Telephone conversation with Gene Lyons, HEW Office of General Counsel, July 31, 1979 (notes on file with Yale Law Journal).

272. This inability or unwillingness to acknowledge that race is "different" appears to be endemic to HEW's Office of Civil Rights as well. See J. Rabkin, HEW's Office of Civil Rights 38 (1979) (unpublished manuscript). 
even to acknowledge the existence of such realities, much less to consider their implications.

In theory, the policymaking process ensures that such contradictions and implications will at least surface and be explored, if not resolved. It does so by encouraging interests potentially disadvantaged by pending legislation to make their concerns known to Congress and the Executive Branch. In the case of the ADA, those interests consisted primarily of the beneficiaries of federally assisted programs, individuals whose participation might be jeopardized if, without an increase in program resources, the participation by members of some other age groups were increased due to the ADA's strictures against age discrimination. In the real world, of course, the notion that, say, CETA jobholders in their teens and twenties would perceive the very real threat to their CETA benefits posed by a ruling that a larger share of CETA job slots go to the elderly, ${ }^{273}$ and would organize politically to resist it, is fanciful. For that reason, HEW and, to a lesser extent, other agencies constituted proxies for such interests. In addition, however, these agencies had their own political and policy interests in defending the way in which they and their grantees distribute their resources and administer their programs. ${ }^{274}$ They also had an interest in helping to define the problem, in pointing out the implications of the proposed legislation, in offering alternative approaches, and in otherwise precipitating consideration of important issues.

The process, however, broke down. With Congress apparently determined to continue stumbling about in the dark, the Executive Branch chose not to help it find its way. From an inadvertent beginning early in 1975 to the amendment of the ADA late in 1978, HEW played an insignificant and wholly reactive role in the design of the legislation, ${ }^{275}$ a role that Congress did nothing to magnify. As a result, the $\mathrm{ADA}$ was enacted by a Congress operating in a vacuum

273. The position of the Civil Rights Commission on the reasonableness of CETA's existing policies, HEW's narrow construction of the "statutory objective" and "reasonable factors other than age" exceptions, and the availability of a private cause of action to challenge the existing distribution of job slots, suggest the reality of the threat.

274. To recognize that HEW has such an interest is not to suggest that it necessarily wishes to-or should-maintain the status quo. Quite the contrary. It is only to acknowledge that it matters-or should matter-to HEW whether such decisions are made by means of an allocative model or a nondiscrimination model, and what the substantive outcomes are.

275. The reasons for this passivity appear to have included division within HEW on the issue, fear of the political consequences of appearing to oppose the interests of the elderly, a sense of futility about influencing a House Committee dominated by Representative Brademas, and normal internal confusion. Telephone interview with Bill Morrill, former Assistant Secretary for Planning and Evaluation, HEW, May 9, 1979 (notes on file with Yale Law Journal). 
of information concerning the nature of the problem, its magnitude, the likely effect of the ADA, and the existence of many alternative approaches to the problem. ${ }^{276}$

Indeed, the Administration failed until 1978 to take even the most obvious first steps toward designing a sensible policy on age discrimination, such as developing an inventory of the ways in which age was in fact used in federally assisted activities. ${ }^{277}$ As of mid-1979, the Administration still had not developed a definition of age discrimination that could be made operational in the context of federally assisted activities, much less determined the extent to which age discrimination actually existed in such activities.

Even when HEW promulgated the governmentwide regulations under the ADA in June 1979, it failed to address several of the most fundamental issues, while resolving others in ways that would increase, rather than reduce, uncertainty as to what laws, policies, and practices might violate the Act. ${ }^{278}$

But just as these congressional and Executive Branch abdications assured that questions of problem definition and appropriateness of remedy would go unanswered-indeed, unasked-the conceptual confusion concerning the nature of age discrimination encouraged those abdications. Having conceived of the problem as one of "ageism" leading to the arbitrary exclusion of the elderly from publicly supported benefits, Congress naturally turned to a familiar legislative remedy for such injustices-the nondiscrimination model of group protection based upon the Title VI analogy. Apparently sensing that this analogy was inapt, however, Congress also gave broad scope to the allocative model by creating broad exceptions and exclusions that countenance the widespread use of age as a classificatory criterion.

Combining these models is not necessarily logically inconsistent; a rule that age criteria shall not be used unless a rational justification can be demonstrated is not self-contradictory. To combine them inadvertently, however, is to set policy adrift from its moorings in considered choice, for each model generates distinctive tendencies and implications that are at war with one another.

276. See pp. 42-49, 55-59 supra.

277. Indeed, fully three years after the ADA was enacted, the Secretary of HEW could still proudly announce that he was taking "an essential first step: to find out whether and how age discrimination exists in laws and official policies." Prepared remarks of Joseph A. Califano, Jr., to the National Journal Conference on the Economics of Aging, at 12 (Nov. 30, 1978).

278. Certainly Congress's adoption of the private cause of action provision, see note 8 supra, coupled with the advocacy and litigation capacity of the aging groups, seems admirably designed to increase the leverage of those groups over the allocation process. 
First, the nondiscrimination model creates a legal right formulated as an abstract rule: no person shall be subjected to discrimination on the basis of age. At least in its pure form, the rule brooks neither qualification nor compromise. Because it is usually linked to notions of fundamental human dignity, a right to be free of discrimination evokes powerful convictions of an entitlement immune to limitation at the instance of anyone other than its possessor. Such rights are often established only after a protracted struggle in which numerous political and ideological obstacles are overcome by insisting upon the absolute nature and primacy of the basic human values that underlie the rights. Although the ADA required no such struggle, its identification with the tradition of civil rights legislation produced the same ideological momentum toward the establishment of unconditional legal rights, a momentum that very nearly succeeded in eliminating the reasonableness exceptions and exclusions from the law in the 1978 amendments and actually succeeded in significantly narrowing the exceptions through the governmentwide regulations issued under the ADA. Not surprisingly, then, a right to be free of discrimination tends to be difficult to adjust or limit; the invocation of prudential or political considerations arguing in favor of change can easily appear to repudiate the underlying values.

In contrast, the allocative model rarely creates legal entitlements in individuals. ${ }^{279}$ Instead, it shapes the exercise of bureaucratic discretion by prescribing distributional criteria to be applied by officials. ${ }^{280}$ Where the nondiscrimination model seeks primarily to vindicate abstract principles resistant to compromise or piecemeal implementation, the allocative model concerns itself primarily with the distribution of resources according to criteria that, by often permitting flexibility and judgment in their application, encourage bargained and incremental solutions. ${ }^{281}$

279. The so-called entitlement programs, however, do create such a right in those who meet the eligibility conditions. See, e.g., The Food Stamp Act of 1977, 7 U.S.C.A. \$ 2014 (1978) (all persons at a certain income level can claim benefits).

280. The criteria for "entitlement" programs, for example, are usually quite detailed. See, e.g., 42 U.S.C. $\$ 1382$ (1976) (defining in detail income definition standards for disabled, aged, or blind individuals seeking entitlement to benefits). Geographical distribution formulas also tend to be quite specific. See, e.g., 20 U.S.C. $\$ 241$ (a) (1976) (allocating funds to local educational agencies in school attendance areas with high concentrations of children from low-income families). Even programs that establish vague criteria at the federal level usually require that detailed allocative standards be developed at the state or local level. See, e.g., 42 U.S.C. $\$ 1396$ a (1976) (requiring states to devise detailed standards in Medicaid program).

281. Questions of resource allocation possess far more natural "trading points" than questions of principle. See T. Schelling, The Strategy of Conflict $21-80$ (1960) (examin- 
Second, the two models differ in the form of their commands. The nondiscrimination model is wholly prohibitory. It neither instructs the person to whom the command is directed what to do or how to do it, nor in any way defines his task or identifies the factors or objectives that should inform his exercise of discretion. Instead, it simply instructs him that he may not take a particular fact or attribute into account in making decisions authorized and governed by other statutes. In contrast, the allocative model is characteristically affirmative: it directs the official to distribute resources and take other positive actions in pursuit of specified objectives, while defining the criteria that must shape exercises of discretion. Accordingly, it implicitly (and often explicitly) reveals both the political choices that animated it and at least the first-order distributional effects that it proposes to generate.

Third, the nondiscrimination model covers an extraordinarily broad range of activities and relationships-for example, all federally assisted programs in the cases of Title VI, section 504, and the ADA. This vast sweep is only possible because of the generality of its nondiscrimination rule and its prohibitory form. The allocative model, however, is employed to address a discrete problem or condition, such as inadequate housing for low-income people or the nutritional needs of the elderly. Thus, the criteria of choice that it prescribes and the zones of discretion that it creates are marked by relatively clear boundaries. Accordingly, the task of agencies and courts in interpreting nondiscrimination laws tends to be more difficult, more controversial, and necessitates more fundamental policy choices, than in the case of allocative laws.

Finally, the nondiscrimination model often can achieve redistributive effects in ways that neither are obvious to the public nor require the creation of a grant program. Section 504, for example, does not direct anyone to do anything, much less divert resources from the nonhandicapped to the handicapped; it simply prohibits discrimination on the basis of handicap. Yet the effect of that law, if enforced, almost certainly will be to increase the level of resources flowing to the handicapped. In contrast, the allocative model's distributional objec-

ing distributional aspects of bargaining); Schuck, Litigation, Bargaining and Regulation, REgulation, July/Aug. 1979, at 26-34 (analyzing relative merits of adjudication and bargaining as regulatory decision mechanisms). If, for example, a nondiscrimination rule prohibits age from being considered in assigning job-training slots, it is difficult to sec how that principle can be compromised. If, on the other hand, a job-training program is being created or funded, it is a relatively simple roatter to reach a bargained determination to earmark a certain portion of the slots for particular age groups. 
tives are explicit and therefore likely to be controversial. This particular attribute of nondiscrimination laws appears to have been very much on the mind of the ADA's chief congressional sponsor, Representative Brademas, who stressed during the final stages of debate on the conference report that the legislation "has the potential of providing substantial additional services and benefits to the elderly without establishing a single new program or requiring additional program funding." ${ }^{282}$ In short, the use of a nondiscrimination model rather than an allocative model relieves Congress of the political risks of having explicitly to allocate scarce resources among competing groups, to raise additional resources by taxation, or to expand the federal budget. It also generates political benefits for Congress with the protected group and has the appearance of benefiting all members of the public equally. The political virtues of such an approach are obvious.

These characteristic differences in the models suggest that the decision to employ one model or the other, or, in the case of the ADA, to adopt elements of both, is likely to be an important judgment entailing significant legal and policy consequences. Each model is appropriate for addressing particular kinds of social problems. Other things being equal, the nondiscrimination model will be most effective when there is reason to believe that decisionmakers are either biased or governed by false stereotypes with respect to a particular fact or attribute, and there is no legitimate reason to consider that fact or attribute in making regulatory or allocative decisions. ${ }^{283}$ Moreover, two features of the nondiscrimination model-its ability to sustain political momentum through its powerful symbolism and resistance to change, and the low-visibility of its potentially far-reaching redistributive effects-commend it to groups that seek respite from the conventional social and political processes by which limited resources are allocated among competing social needs. ${ }^{284}$ By escaping the competitive constraints of those processes, such a group can hope to reaffirm the primacy of the nondiscrimination principle, reduce or eliminate the discretion of unsympathetic decisionmakers, and maximize the flow of resources to its members.

282. See note 103 supra.

283. Other considerations bearing upon the model's appropriateness and effectiveness in any particular instance include the difficulty in proving discriminatory purpose, the social consequences of adopting a disproportionate-impact criterion of discrimination, and the distributional consequences of eliminating the discrimination.

284. For a discussion of this phenomenon with respect to Title VI, Title IX, and $\$ 504$, see J. Rabkin, supra note 272 , at $41-44$. 
The allocative model, on the other hand, is best suited to address problems that cannot properly be resolved by resort to a preexisting, impersonal, general rule. Such problems implicate a number of competing, highly interdependent, and frequently changing ends whose weights are neither static nor objectively determined. ${ }^{285}$ The allocative model assumes that those ends must be balanced and compromised through a flexible, cybernetic, contingent, and ultimately political process. It assumes that such a process cannot be reduced to abstract rules or to fixed definitions of need, but must instead be free to take account of many considerations and different indices of need. Most significant policy questions with which legislators and administrative agencies grapple are essentially of this kind; growing social complexity and interdependence are probably increasing their incidence and importance.

To contrast the nondiscrimination and allocative models, however, is not to suggest that these remedies and the problem definitions that they reflect are mutually exclusive. ${ }^{286}$ Comparison of the two models is intended only to suggest that the choice of statutory form generates important consequences that in the case of the $\mathrm{ADA}$ were never considered by the principal policymaking institutions.

On the basis of the evidence produced in the congressional hearings, the Civil Rights Commission study, and HEW's administrative hearings on the governmentwide regulations, one is forced to the following conclusion: if federal policy fails to adequately protect and advance the interests of the elderly-a question well outside the scope of this Article ${ }^{287}$-that failure is not because of any significant pattern of "ageism" on the part of federal officials or federal grantees but instead

285. For a discussion of the suitability of various decisionmaking processes in resolving such problems, see Fuller, The Forms and Limits of Adjudication, 92 Harv. L. Rev. 353 , $394-409$ (1978) [hereinafter cited as Adjudication]; Fuller, Mediation-Its Forms and Functions, 44 So. CAL. L. REv. 305, 334-37 (1971) [hereinafter cited as Mediation]. For an exploration of related issues, see Eisenberg, Participation, Responsiveness, and the Consultative Process: An Essay for Lon Fuller, 92 HARv. L. REv. 410, 423-26 (1978).

286. As discussed above, a nondiscrimination law that effectively reduces the effects of bias in the provision of housing, jobs, or other social benefits will certainly affect the distribution of such benefits. See p. 87 supra. Indeed, many of the proponents of the ADA supported it precisely because of its presumed redistributive effects. See 121 ConG. REc. 37,297 (1975) (remarks of Rep. Brademas). A statute that increases the distribution of such benefits to certain groups could well dissolve inaccurate stereotypes, thereby reducing the amount of bias suffered by them.

287. An answer would require that this question be formulated more precisely. Even in that event, it would depend at a minimum upon numerous value judgments concerning, for example, the "correct" level of total resources allocated by tax, expenditure, and regulatory decisions of government; the share of those resources that "ought" to go to the elderly; and the "needs" of the elderly. 
reflects the fact that society has chosen to allocate its resources in ways that do not adequately meet the needs of that group.

If Congress, having judged that a problem did indeed exist, had concluded that it lay not in "ageism" but in inadequate program benefits to the elderly, numerous allocative options would have been available to it. Taking into account the needs and capacities of particular age groups, as well as any political considerations that it deemed relevant, Congress could have decided that certain age groups had not received an appropriate share of benefits in certain federally assisted programs and that it wished to increase that share. Once the problem had been defined in this way, Congress could have affirmatively addressed it by directing that such benefits be allocated on the basis of need as defined by whatever criteria Congress deemed appropriate for measuring that need. Numerous conventional statutory mechanisms consistent with any level of fiscal constraint were available for this purpose. ${ }^{288}$ To have used these allocative approaches would not have foreclosed the additional and complementary option of adopting a nondiscrimination law limited to discrete practices, such as agelimited medical school admissions practices, thought to be invidious. ${ }^{289}$

Congress, for reasons suggested above, rejected such refined, targeted, problem-oriented approaches in favor of the peculiar hybrid that constitutes the ADA. What consequences can be expected to flow from its choice? Although the most important effects of the ADA, as of any social reform, may well be those that cannot now be anticipated, several predictions may nevertheless be ventured. First, the ADA is likely to increase the proportion of total program resources allocated to the elderly. If Congress may be said to have had any single coherent expectation in enacting the $A D A$, it was that the elderly would receive a larger share of program benefits in a world free of "ageism." But if

288. If Congress were prepared to create new programs or authorize additional expenditures, it could have enacted programs targeted on the elderly or increased the appropriations under existing programs. Alternatively, it could have earmarked a certain percentage of existing general program funds to be spent on the elderly, directed program administrators to spend more of the existing funds on the elderly, or increased the funding of programs for the elderly while reducing other programs by a like amount. See M. Kirst, Government Without Passing Laws 62.88 (1965) (discussing statutory and nonstatutory devices for allocating resources).

289. Examples of such nondiscrimination laws already cnacted include the Comprehensive Alcohol Abuse and Alcoholism Prevention, Treatment, and Rehabilitation Act of 1970, 42 U.S.C. $\$ 4581$ (a) (1976) (prohibiting discrimination in admission or treatment of alcohol abusers or alcoholics by federally assisted hospitals or outpatient facilities solely because of individual's alcohol abuse or alcoholism) and the Drug Abuse Office and Treatment Act of 1972, 21 U.S.C. $\$ 1174$ (a) (1976) (prohibiting discrimination in admission or treatment of drug abusers by federally assisted hospitals solely because of individual's drug abuse or drug dependence). 
resource levels remain unchanged, increases for the elderly will be at the expense of members of every other age group. One can anticipate, then, that the ADA will tend to intensify conflict and friction between age groups in their pursuit of public and private benefits. ${ }^{200}$

Second, whatever redistribution occurs between age groups as a result of the ADA is likely to be relatively random compared to that effected by an allocative law. Redistribution through nondiscrimination laws is not the result of affirmative, problem-oriented, visible choices by Congress or agencies. Rather it is a consequence of relatively low-visibility actions reflecting decisions not to consider certain factors. In the case of the ADA, such actions generally will be taken by bureaucrats and by courts in spasmodic fashion as groups challenge particular uses of age or particular distributional patterns induced by the use of non-age factors. In contrast, under an allocative law, such actions will be taken in relatively routinized fashion as part of an ongoing program.

Third, one can anticipate that the cost effectiveness of some social programs will decline as program managers feel obliged (1) to serve more elderly and fewer younger people in situations in which the former are more costly to serve, or less likely to benefit, than the latter; (2) to abandon age criteria in favor of other criteria that less accurately measure the characteristic for which age was a proxy, or that measure it only at greater cost; and (3) to undertake costly new data collection activities in order to identify the age composition of their beneficiary populations, necessitating (in the absence of a budget increase) a corresponding reduction of actual services. ${ }^{291}$ Whether such consequences,

290. One can well imagine that an action to increase the level of program services to the elderly could generate litigation on behalf of children's groups contending that an age criterion has been used to deprive children of their "fair share" of services in violation of the ADA. In such a case, program officials would be in a position similar to that of employers subjected to employment discrimination claims by different minority groups. Cf. Sears, Roebuck \& Co. v. Attorney General et al., [1979] 19 Lab. Rel. Rep. [19 Fair Empl. Prac. Cas.] 916 (dismissing complaint contending that attempts by federal government to extend special legal protections to numerous groups simultaneously through civil rights laws unconstitutionally subjects employers to mutually inconsistent constraints).

It is also possible that this increased competition between age groups will generate an increase in the total resources expended in federally assisted social programs. If the share going to the elderly is increased, other age groups can be cxpected to vigorously resist a decline in "market share" by pressing for "hold harmless" treatment.

The author's observation, confirmed by others with policymaking experience, is that the condition of Pareto optimality-the condition that any change will leave no person worse off than he or she was before-is rarely violated in the case of policy changes likely to have clearly visible redistributive effects. Should these efforts succeed, the increases would relax the resource constraint somewhat and might restrict the elderly to their present share. Whether this would moderate the intergroup conflict or simply cncourage more intense advocacy and conflict is unclear. Certainly, the supply of program resources will, under any conceivable set of circumstances, remain far below demand.

291. See note 160 supra. 
on balance, are to be regarded as desirable or not is of course a normative judgment upon which reasonable persons may differ.

Fourth, the ADA will generate much programmatic uncertainty, magnified in some important respects by HEW's governmentwide regulations. In light of those regulations, it is not altogether clear, for example, that CETA, job training, vocational education, and other such programs may maintain their present policies of concentrating funds upon persons in their prime working years, or that social service agencies may continue to devote the vast majority of federal day-care funds to children, rather than to adults in need of day care. In view of the stakes and the ADA's incentives for litigation, it would be surprising if legal and political conflicts did not erupt over these and similar issues. Again, whether changes in the age composition of the population served by particular programs are desirable depends upon one's point of view. But few social programs will be immune from the threat of challenges to their most basic policies, policies that in many cases represent the hard-won fruits of earlier reform struggles.

The final and perhaps most far-reaching consequence to be anticipated relates to the effect of the ADA and the governmentwide regulations upon the manner in which, and the institutions by whom, decisions concerning the allocation of resources in federally assisted programs will be made. A number of considerations, taken together, strongly suggest that although the Act reposes primary regulatory and enforcement authority in the departments and agencies, the courts also will perform a central policymaking role under the ADA. To begin with, the governmentwide regulations neither significantly specify the vague statutory language, nor resolve critical legal and policy issues such as the status of cost-benefit and cost-effectiveness considerations justifying the use of age criteria. ${ }^{292}$ Such issues will perforce be resolved by the courts. Moreover, individual agencies, in issuing and enforcing agency-specific ADA regulations, will surely characterize their existing distributional patterns and policies as eminently reasonable under one or more of the exceptions. In this event, the powerful incentives for private litigation added by the 1978 amendments will enable those dissatisfied with program policies to carry their arguments into a new, perhaps more sympathetic forum.

The prospect of judicial supervision over federal, state, and local agency decisions about appropriate program policies and resource allocations is troubling. Whether the agency is determining the extent to which it should target CETA job-training funds on teenagers or

292. See pp. 75-76 supra. 
senior citizens, which mix of services Community Mental Health Centers should provide, what age groups an adoption agency should concentrate on placing, or what the office hours of a local social service agency should be, ${ }^{293}$ the agency will be confronting problems of a type addressed most appropriately by the kind of pragmatic process intrinsic to the allocative model. ${ }^{294}$

By encouraging courts to resolve such problems, we invite failure. Without decision rules to look to, without a methodology for identifying appropriate criteria or assigning them appropriate weights, courts will be cast adrift on a sea of discretion. Constrained by procedural norms that hobble their ability to trace out the effects of interdependencies, to adjust to changes in the environment, or to develop political consensus on behalf of a solution, their decisions are unlikely to constitute sound policy. Under such circumstances, courts will tend to pursue one of two courses, or worse yet, they may pursue both simultaneously. Lacking the tools to perform the task at hand, a court may simply transform the problem into one that it can handle by radically simplifying the reality in which the problem is rooted and redefining it as one that can be resolved by recourse to a preexisting rule. ${ }^{295}$ The nondiscrimination model encourages the search for such a rule, and Title VI law will remain a seductive analogy from which the rule's substantive content can be derived. ${ }^{206}$ Alternatively, courts

293. If these examples seem far-fetched, note that Secretary Califano, in issuing the governmentwide regulations, stated:

The Act and these regulations seek to root out subtle as well as obvious discrimination. For example, the hours that a facility operates or the kind of services a program offers may determine the age groups who use the program. If these decisions have an adverse effect on persons of a particular age, they will not be permitted unless they are fully justified.

Statement of Joseph A. Califano, Jr., June 5, 1979, at 7.

294. Those situations in which the allocative model is more appropriate have been characterized thus:

[A]n optimum solution can normally be arrived at only by vesting a single decisionmaker with "managerial" authority-by which I mean authority not only to apply relevant criteria, but to determine how much weight each criterion is to receive and to change those weights as new objectives and criteria may require. In such cases the decisionmaker may not use improper criteria, and should apply the same criteria to all those similarly situated, but while he holds his position he can appropriately give to all proper criteria whatever weight he thinks appropriate.

Eisenberg, supra note 285 , at 425 .

295. As Professor Fuller put it in a slightly different context, "The transformation by which economic relations that ought to remain flexible tend to crystallize into 'rights' is, in effect, the same process $I$ attempted to describe when I spoke of cases where adjudication, instead of accommodating its forms to a polycentric problem, has accommodated the problem to its forms." Adjudication, supra note 285, at 404. Elsewhere, Professor Fuller noted that, "The standard American solution for polycentric problems . . . is to move toward 'judicalizing' or 'Iegalizing' the administrative tasks they involve." Mediation, supra note 285 , at 337 .

296. In this way the ADA will grant to judges a high degree of policy discretion. In consequence, the social policy that the ADA must shape may be fashioned less by institu- 
may abandon their adjudicatory lifejackets and plunge heroically into the rising waters of allocative problem-solving. But they are soon likely to find themselves in over their heads, for their ability to devise suitable criteria for deciding such cases is, and is likely to remain, severely limited.207

Judicial policymaking under the ADA, however incompetent it may prove to be, nonetheless appears inevitable. When it occurs, it will doubtless be perceived as a judicial arrogation of powers that ought properly to be exercised elsewhere. ${ }^{298}$ In the end, however, the abject institutional failures of Congress and the Executive Branch in the case of the ADA necessarily put this question in a somewhat different and more uncertain light. For Congress to enact a law based largely upon conflicting premises and then to refuse to define or even guide its policy except through broad intimations of sentiment is to require other institutions to fill this void. ${ }^{299}$ For the Executive Branch first to abdicate its policy-shaping role in the legislative process and then effectively to delegate the hard discretionary choices to the courts is not merely to invite judicial policymaking but to compel it..00 When this comes to pass, and the judiciary has been duly denounced as "imperial," it will be well to recall that in this case, at least, its crown, like that offered to Shakespeare's Caesar, was neither requested nor usurped but was pressed upon it by politicians at the Capitol.

tions that characteristically engage in social choice than by those that are relatively illequipped to do so (and are obliged, even when incontrovertibly doing so, to pretend that they are doing otherwise). The explanation for this turnabout may lie as much in the fiction that a nondiscrimination law supplies a court with authoritative, preexisting rules that need only be elaborated logically, as it does in any belief that courts will somehow make sounder, fairer policy judgments.

297. See, e.g., D. Horowirz, The Courts and Social Policy 106-70 (1977) (discussing deficiencies of judicially developed criteria for allocation of education funds); $A d j u d i c a-$ tion, supra note 285 , at 400 (problems in allocating economic resources not appropriate to adjudication). But see Chayes, The Role of the Judge in Public Litigation, 89 Harv. L. REv. 1281, 1308 (1976) (courts have unique capacities to perform complex tasks); Eisenberg \& Yeazell, The Ordinary and the Extraordinary in Institutional Litigation (courts have long performed tasks of equal or greater complexity) (unpublished, forthcoming in Harvard Law Review).

298. Cf. A. Bickel, The Supreme Court and the Idea of Progress 175 (1970) (courts too remote to deal with complex problems); Glazer, Should Judges Administer Social Services? 50 PUB. INTEREST 64 (1978) (bureaucrats and administrators better equipped than courts).

299. As Louis Jaffe has put it in a closely analogous context, Congress has simply delegated the policymaking to others and "hope[d] for the best." L. JAFFe, Judicial Control of Administrative Action 49 (1965).

300. Some commentators have suggested that the courts, by resort to certain doctrinal strategies, refuse to play this role where fundamental policy issues have been left unresolved by Congress. E.g., T. Lowr, THE END OF LiberalisM 128-56 (1969) (discussing nondelegation doctrine); Gewirtz, Congress, the Courts and Executive Policy-Making, 40 LAW \& Contemp. Prob. (No. 3) 46, $49-80$ (1976) (nondelegation doctrine and clear statement doctrine). 


\title{
The Yale Law Journal
}

Volume 89, Number 1, November 1979

\author{
Alice Armitage Colburn \\ Editor-in-Chief
}

\author{
Boris Feldman \\ Note \& Topics Editor \\ James A. Geraghty \\ Scott M. Matheson \\ Roberta Romano \\ Kenneth T. Roth \\ Note Editors
}

\author{
Peter A. Barnes \\ Managing Editor
}

Mark S. Campisano

Morgan J. Frankel

R. Laird Hart

Robert A. Katzmann

James C. Snipes

Article \& Book Review Editors
William B. Beekman

Craig B. Brod

David M. Crowe

Jeffrey P. Cunard

Neil R. Ellis

Richard H. Fallon

Simon Friedman

Gregory P. Goeckner
Isabelle R. Gunning

Theodore F. Haas

John C. Harrison

Frederick M. Lawrence

David Nimmer

Russell V. Randle

Julie A. Roin

Douglas H. Rosenberg
Anne C. Ryan Judith A. Shulman Richard S. Soble Donald K. Stockdale, Jr. Debra A. Valentine Vern R. Walker Robert L. Willmore Michael Woodford

Secretaries to the Editors Edna I. Scott, Pamela Willmott

\section{Student Contributors to This Issue}

Craig B. Brod, The Securities Exchange Act and the Rule of Exclusive Federal Jurisdiction

Richard H. Fallon, Jr., Protecting the Public Interest: Nonstatutory Suits by the United States

Morgan J. Frankel, Tax Treatment of Artists' Charitable Contributions

Roberta Romano, Segregating Schools: The Foreseeable Consequences of Tuition Tax Credits

James C. Snipes, Due Process and Ex Parte Contacts in Informal Rulemaking 